\title{
EL TRASLADO TRANSFRONTERIZO DE LA SEDE SOCIAL: LA NECESIDAD DE ARTICULAR UNA RESPUESTA DESDE LA ÓPTICA DEL DERECHO SOCIETARIO EUROPEO
}

\author{
ALBERTO QUINTAS SEARA ${ }^{1}$ \\ alberto.quintas@udc.es
}

Cómo citar/Citation

Quintas Serara, A. (2017).

El traslado transfronterizo de la sede social: la necesidad de articular una respuesta desde la óptica del derecho societario europeo. Revista de Derecho Comunitario Europeo, 57, 517-574. doi: https://doi.org/10.18042/cepc/rdce.57.04

\section{Resumen}

El traslado transfronterizo de la sede social se configura como una operación de gran utilidad para las empresas europeas en la medida en que les permite elegir, con posterioridad a su creación, el entorno legislativo que mejor se adapte a sus necesidades, lo que termina por traducirse en unos mayores niveles de productividad y competitividad a nivel internacional. Por ello, el objetivo de este trabajo consiste, por una parte, en aproximarnos a los principales obstáculos jurídicos que afectaban a la realización efectiva de estas operaciones, así como los importantes avances introducidos por la jurisprudencia del Tribunal de Justicia de la Unión Europea (TJUE) en materia de libertad de establecimiento y, por otra parte, en abordar la necesidad de dar respuesta a través de una norma de derecho societario europeo a la problemática que en la actualidad sigue planteando el traslado transfronterizo del domicilio social,

1 Investigador FPU, Universidad de A Coruña. Este trabajo se ha realizado en el marco del proyecto de $\mathrm{I}+\mathrm{D}+\mathrm{i}$ financiado por el Ministerio de Economía y Competitividad bajo el título "La reforma de la imposición societaria en la UE: cuestiones generales y problemática del régimen de las operaciones de reorganización empresarial» (DER2013-47516-P). 
con especial referencia a la cuestión relativa a su posible impacto sobre la competencia normativa entre Estados miembros y entre formas societarias nacionales y formas societarias de naturaleza europea.

\title{
Palabras clave
}

Traslado transfronterizo de la sede social; libertad de establecimiento; decimocuarta directiva de derecho societario

\section{THE CROSS-BORDER TRANSFER OF THE REGISTERED OFFICE: THE NEED TO PROVIDE A SOLUTION FROM THE PERSPECTIVE OF EUROPEAN COMPANY LAW}

\begin{abstract}
The cross-border transfer of the registered office shall be regarded as a very useful operation for European companies, since it allows them to choose after their creation the legislative framework that best suits their needs, resulting in higher levels of productivity and competitiveness. Therefore, the aim of this work is, on the one hand, to approach to the the main legal obstacles to these operations, as well as the significant advances made by the ECJ case law on freedom of establishment, and, on the other hand, to address the need to provide a solution from the perspective of European Company Law to the problems that still negatively affect the cross-border transfer of the registered office, with particular reference to the possible impact on regulatory competition between Member States and between national corporate forms and European corporate forms.
\end{abstract}

\section{Keywords}

Cross-border transfer of the registered office; freedom of establishment; Fourteenth Company Law Directive.

\section{LE TRANSFERT TRANSFRONTALIER DU SIEGE STATUTAIRE: LA NECESSITE D'UNE REPONSE PAR LE DROIT EUROPEEN DES SOCIETES}

\section{Résumé}

Le transfert transfrontalier du siège social est configuré comme une opération très utile pour les entreprises européennes dans la mesure où leur permet de choisir, après sa création, le cadre législatif qui convient le mieux à leurs besoins, résultant en une amélioration de productivité et de la compétitivité internationale. Par conséquent, le but de cet article est d'analyser, d'une part, les principaux obstacles juridiques affectant la réalisation effective de ces opérations ainsi que des avancées introduites par la juris- 
prudence de la CJCE sur la liberté d'établissement, et, en outre, la nécessité d'apporter une réponse par le Droit Européen des Sociétés aux problèmes que pose actuellement le transfert transfrontalier du siège social, avec une référence particulière à la question de son impact possible sur la concurrence normative entre les États membres et entre les formes de sociétés nationales et les formes de sociétés européennes.

\section{Mots clés}

Transfert transfrontalier du siège social; liberté d'établissement; Quatorzième Directive sur le Droit des sociétés. 


\section{SUMARIO}

I. MODO DE INTRODUCCIÓN: UNA APROXIMACIÓN A LA PROBLEMÁTICA JURÍDICA QUE PLANTEABA EL TRASLADO TRANSFRONTERIZO DE LA SEDE SOCIAL DE LAS SOCIEDADES CONSTITUIDAS EN LOS DIFERENTES ESTADOS MIEMBROS. II. LAS LIMITACIONES DE LA JURISPRUDENCIA DEL TJUE EN RELACIÓN CON EL TRASLADO TRANSFRONTERIZO DE LA SEDE SOCIAL, ASÍ COMO DEL USO DE «VÍAS INDIRECTAS» PARA LLEVAR A CABO ESTAS OPERACIONES. III. LA NECESIDAD DE DAR UNA RESPUESTA AL PROBLEMA DEL TRASLADO TRANSFRONTERIZO DEL DOMICILIO SOCIAL DESDE EL PLANO DEL DERECHO POSITIVO EUROPEO. 1. Consideraciones generales. 2. Algunas cuestiones clave acerca de la futura decimocuarta directiva en materia de derecho societario europeo. IV. LA INTENSIFICACIÓN DE LA COMPETENCIA NORMATIVA ENTRE ESTADOS MIEMBROS EN EL PLANO DEL DERECHO SOCIETARIO: UN «EFECTO SECUNDARIO»DE LA JURISPRUDENCIA DEL TJUE EN MATERIA DE LIBERTAD DE ESTABLECIMIENTO Y DE LA POSIBLE ADOPCIÓN DE LA DECIMOCUARTA DIRECTIVA. V. CONCLUSIONES.

\section{A MODO DE INTRODUCCIÓN: UNA APROXIMACIÓN A LA PROBLEMÁTICA JURÍDICA QUE PLANTEABA EL TRASLADO TRANSFRONTERIZO DE LA SEDE SOCIAL DE LAS SOCIEDADES CONSTITUIDAS EN LOS DIFERENTES ESTADOS MIEMBROS}

El traslado transfronterizo de la sede social siempre ha suscitado un gran interés entre las sociedades de los diferentes Estados miembros habida cuenta de que puede configurarse como un mecanismo eficaz orientado, por ejemplo, a generar vía «nacionalización» una mayor confianza en los consumidores del país en el que la sociedad lleva a cabo la mayoría de sus actividades comerciales $^{2}$, o bien a la búsqueda de una ventaja en el plano del derecho societario (p.ej. en relación con el régimen de responsabilidad de los administradores o los derechos participación de los trabajadores), del derecho concursal, o

2 En este sentido, véase Fernando ESTEBAN DE LA ROSA, «El nuevo régimen de la transferencia internacional de la sede social en el sistema español de Derecho Internacional Privado», Cuadernos de Derecho de Comercio, núm. 54, 2010, p. 76. 
del derecho tributario ${ }^{3}$. Sin embargo, lo cierto es que, tradicionalmente, la realización efectiva de estas operaciones planteaba una serie de cuestiones problemáticas tanto en el ámbito conflictual como en el plano de las normas materiales de los Estados miembros aplicables a las mismas.

A este respecto, y en relación con el ámbito conflictual, no puede perderse de vista que el hecho de que la sede social se integre o no en el punto de conexión configurado por las normas de conflicto del Estado miembro de origen y/o destino va a determinar si la operación de traslado conlleva o no una modificación de la lex societatis (transferencia de derecho $v$. transferencia de hecho), debiendo, en caso afirmativo, establecerse cuál será la lex societatis aplicable a la operación. Por su parte, y desde la óptica del derecho material, los principales problemas asociados a estas operaciones aparecían vinculados al mantenimiento de la personalidad jurídica de la sociedad en aquellos supuestos en los que se produce un cambio de la lex societatis ${ }^{4}$, a las condiciones y requisitos impuestas por el Estado miembro en cuestión para su realización (p.ej. en relación con la mayoría necesaria para la aprobación del acuerdo de traslado, el contenido y forma del mismo, los requisitos de la convocatoria de

3 De hecho, en una consulta pública lanzada por la Comisión Europea en el año 2013, los principales factores citados por las empresas europeas para trasladar su domicilio social eran por este orden: un régimen fiscal favorable; un derecho societario favorable; un "clima de negocios» favorable; un marco legal estable, y un derecho concursal favorable (véase COMISIÓN EUROPEA, «Feedback statement. Summary of responses to the public consultation on cross-border transfers of registered offices of companies», Septiembre 2013, pp. 8-9 y 12, disponible en: http://ec.europa.eu/internal_market/consultations/2013/seat-transfer/docs/summary-of-responses_en.pdf (consultado por última vez el 8-2-2017). En este sentido, no puede perderse de vista que, en la mayoría de Estados miembros, el domicilio social de una sociedad constituye uno de los criterios de conexión determinantes de la residencia fiscal y, por ende, de la sujeción al impuesto sobre sociedades (véase, a título de ejemplo, los arts. 7.1 y 8.1 de la Ley 27/2014, de 27 de noviembre, del Impuesto sobre Sociedades (BOE núm. 288, de 28 de noviembre de 2014, p. 96939). Por otra parte, conviene resaltar que la búsqueda de un entorno legislativo en materia societaria, concursal o fiscal más favorable, no solo podría suponer un ahorro en costes para la sociedad, sino que también impactaría de forma directa en la facilidad para obtener recursos financieros por parte de potenciales accionistas o de entidades bancarias.

4 A este respecto, no conviene perder de vista cómo el art. 220 del Tratado Constitutivo de la Comunidad Económica Europea (TCEE), hoy eliminado del Tratado de Funcionamiento de la Unión Europea (TFUE), ya hacía referencia, entre otras cuestiones, a la necesidad de que los Estamos miembros entablasen negociaciones con el objetivo de asegurar «el mantenimiento de la personalidad jurídica en caso de traslado de su sede de un país a otro». 
la junta de accionistas o los derechos de los socios minoritarios, trabajadores y acreedores) o a los aspectos registrales de la operación de traslado5.

Si partimos del plano conflictual, conviene recordar que los Estados miembros han optado tradicionalmente entre dos modelos de determinación de la lex societatis: a) el «modelo de incorporación/constitución» (Gründungstheorie), seguido por Estados miembros como Dinamarca, Finlandia, Irlanda, Países Bajos, Reino Unido o Suecia, en el que prima el criterio subjetivo de la voluntad de los socios, y en virtud del cual las sociedades deben regirse por las leyes del Estado donde fueron constituidas o registradas con independencia de dónde esté localizada su sede real o efectiva y de la nacionalidad de sus socios, o b) el «modelo de la sede real» (Sitztheorie), seguido por Estados miembros como Alemania, Austria, Bélgica, Francia, Grecia, Luxemburgo o Portugal, que pivota sobre un criterio de corte objetivo, y según el cual las sociedades deben regirse por las leyes del Estado en cuyo territorio se encuentre situada su sede de administración central o su establecimiento principal (según las diferentes variantes del modelo), con independencia de dónde se hubieran constituido o registrado ${ }^{6}$. No obstante, en la actualidad, resulta difícil encontrar Estados miembros que acojan en sus respectivos sistemas legislativos las versiones «clásicas» de la teoría de la incorporación o de la teoría de la sede real, de forma tal que, aun cuando a efectos de claridad expositiva puedan

5 Sobre esta cuestión, véase Francisco José GARCIMARTÍN ALFÉREZ, «El traslado del domicilio social al extranjero. Una visión facilitadora», Revista de Derecho de Sociedades, núm. 16, 2001, pp. 108-110; o Diana SANCHO VILLA, La transferencia internacional de la sede social en el Espacio Europeo, Eurlex, Madrid, 2001, pp. 145146.

6 Un buen análisis de los caracteres definidores, fundamentos, ventajas y problemática asociada a los modelos de incorporación y de la sede real puede encontrarse en Pilar BLANCO-MORALES LIMONES, La transferencia internacional de la sede social, Aranzadi, Pamplona, 1997, pp. 47-85. Al margen de estas dos tendencias mayoritarias, podrían identificarse sistemas mixtos tales como el «modelo de diferenciación» o el "modelo de superposición" que combinan ambos criterios de conexión para determinar la lex societatis aplicable a las relaciones ad intra y ad extra de la sociedad, de forma tal que esta, a diferencia de los modelos anteriores, podría no ser la misma. Sobre esta cuestión, resulta clarificador el análisis efectuado por Francisco José GARCIMARTÍN ALFÉREZ, «La Sitztheorie es incompatible con el Tratado CE. Algunas cuestiones del Derecho internacional de sociedades iluminadas por la STJCE de 9 de marzo de 1999», Revista de Derecho Mercantil, núm. 232, 1999, pp. 648-652. 
encuadrarse en alguno de los modelos anteriores, lo cierto es que en la práctica nos encontraremos ante diferentes variantes de los mismos ${ }^{7}$.

De este modo, en aquellos Estados miembros que optaban por el modelo de constitución, la operación en virtud de la cual una sociedad constituida conforme a su derecho nacional (e incorporada en su territorio) trasladaba al extranjero su sede social se traducía, con carácter general, en una modificación de la lex societatis (al alterarse el factor de conexión que determina la sujeción de la sociedad a la legislación del Estado miembro de origen) con independencia de que dicho traslado se acompañase o no de una transferencia de la sede real de la sociedad ${ }^{8}$. A este respecto, es importante tener presente que dicha modificación de la lex societatis no implica necesariamente la pérdida de personalidad jurídica de la sociedad en cuestión, sino que ambas cuestiones presentan una naturaleza autónoma, pues la primera es propia del ámbito conflictual mientras que la segunda se inscribe en el plano del derecho material. Así, en estos supuestos de transferencia de derecho de la sede social al extranjero podía darse el caso de que la sociedad tuviese que disolverse en el Estado miembro de origen y re-constituirse en el Estado miembro de destino, o bien que la operación pudiera llevarse a cabo con mantenimiento de la personalidad jurídica, lo cual requería que esta posibilidad estuviese admitida por el ordenamiento jurídico de los Estados miembros de origen y destino?.

Así, y a título de ejemplo, cabría señalar cómo, dentro del conjunto de Estados miembros que optaban por el modelo de constitución, podían encontrarse sistemas legislativos (p. ej. España o Italia) en los que se reclamaba la aplicación unilateral de la ley del foro en aquellos supuestos en los que la relación jurídico-societaria presentaba una fuerte vinculación con el territorio del Estado en cuestión (véase, por una parte, el art. 5.2 del Decreto Legislativo 1564/1989, de 22 de diciembre, por el que se aprueba el texto refundido de la Ley de Sociedades Anónimas (BOE núm. 310, de 27 de diciembre de 1989, p. 40012), junto con el art. 6.2 de la Ley 2/1995, de 23 de marzo, de Sociedades de Responsabilidad Limitada (BOE núm. 71, de 24 de marzo de 1995, p. 9181) y, por otra parte, el art. 25.1 in fine de la Ley núm. 218, de 31 de mayo de 1995, sobre la Reforma del Sistema Italiano de Derecho Internacional Privado). Este tipo de modelos de estructura compuesta o compleja también podía observarse en otros Estados no miembros de la Unión Europea como Suiza (véase arts. 156 a 159 de la Ley Federal de 18 de diciembre de 1987 de Derecho Internacional Privado, RO 1988 II 1776, RS 291). Sobre esta cuestión, véase SANCHO VILLA, op. cit., nota 5 , pp. 82-85.

8 En este sentido, véase Paola RODAS PAREDES, Libertad de establecimiento y movilidad internacional de las sociedades mercantiles, Comares, Granada, 2011, p. 40.

9 En este sentido, véase GARCIMARTÍN ALFÉREZ, op. cit., nota 5, pp. 112-114, o BLANCO-MORALES LIMONES, op. cit., nota 6, pp. 33-34, quien apunta que «en 
Por ejemplo, en el Reino Unido, para que las sociedades constituidas con arreglo a su legislación societaria doméstica pudieran trasladar al extranjero su sede social y adquirir la nacionalidad del Estado miembro de destino era necesaria la adopción de una ley particular del Parlamento británico, de forma tal que, con carácter general, podría afirmarse que la operación de traslado transfronterizo de la sede social con cambio de la lex societatis determinaba la disolución de la sociedad en su Estado miembro de origen ${ }^{10}$. En el supuesto inverso, la situación no era mucho mejor, ya que, en la medida en que solo podían tener localizado su domicilio social en Reino Unido las sociedades constituidas de acuerdo con la Companies Act de 1985 o con arreglo a la legislación societaria aplicable en Irlanda del Norte, todas las sociedades extranjeras que trasladasen su sede social al Reino Unido no serían reconocidas como tales, debiendo disolverse en su Estado miembro de origen y reconstituirse conforme al ordenamiento británico ${ }^{11}$. Siguiendo una línea similar, en los Países Bajos, tanto la operación de traslado de la sede social al extranjero por parte de sociedades constituidas con arreglo a su ordenamiento interno como el traslado de la sede social de sociedades extranjeras a su territorio conllevaban una modificación de los estatutos sociales de la sociedad que precisaba de la aprobación del Ministerio de Justicia, la cual normalmente no era concedida, frustrando de este modo la posibilidad de llevar a cabo estas operaciones con mantenimiento de la personalidad jurídica ${ }^{12}$.

Sin embargo, lo cierto es que también podían encontrarse Estados representantes del modelo de constitución que disponían de normas específicas en sus respectivos ordenamientos internos destinadas a posibilitar el traslado transfronterizo de la sede social con cambio de la lex societatis y mantenimiento de la personalidad jurídica. En este sentido, cabría traer a colación el caso de Italia, donde la transferencia de derecho de la sede social desde y hacia su territorio sin necesidad de disolución de la sociedad en su Estado miembro de origen resultaba posible en virtud de lo establecido en el art. 25.3 de la Ley 218, de 31 de mayo de 1995, sobre la Reforma del Sistema Italiano de Derecho Internacional Privado, existiendo numerosas resoluciones judiciales

este extremo, la aplicación cumulativa de ambas leyes, es contemplada como requisito imprescindible para evitar situaciones claudicantes, por la práctica unanimidad de la doctrina».

10 En este sentido, véase Luis FERNÁNDEZ DEL POZO, «Transferencia internacional de sede social», Revista General de Derecho, núm. 591, 1993, p. 11892.

11 En este sentido, véase SANCHO VILLA, op. cit., nota 5, pp. 287-288.

12 Sobre esta cuestión, véase Eddy WYMEERSCH, "The Transfer of the Company's Seat in European Company Law», ECGI Working Paper Series in Law, núm. 8, 2003, p. 8. 
favorables al respecto ${ }^{13}$. Fuera del ámbito de la UE, aunque en una línea similar a Italia, también Suiza permitía estas operaciones con mantenimiento de la personalidad jurídica sobre la base de lo dispuesto en los arts. 161 a 164 de la Ley Federal de 18 de diciembre de 1987 de Derecho Internacional Privado ${ }^{14}$.

Por lo que respecta al caso de España, que optaba por un modelo determinación de la lex societatis de domicilio-constitución (plasmado en los arts. 5.1 de la LSA y 6.1 de la LSRL), el mantenimiento de la personalidad jurídica de la sociedad en el marco de una operación de traslado transfronterizo de su sede social al extranjero quedaba supeditada a la existencia de un convenio internacional que admitiese dicha posibilidad, tal y como se recogía en los arts. 149.2 de la LSA y 72.2 de la LSRL ${ }^{15}$. Por ello, y en la medida en que el

13 Sobre esta cuestión, véase SANCHO VILLA, op. cit., nota 5, pp. 22-23.

14 De este modo, el traslado transfronterizo de la sede social a Suiza por parte de sociedades constituidas con arreglo a un ordenamiento extranjero quedaba supeditado simplemente a la verificación de las siguientes condiciones: a) que la legislación del Estado de origen permitiese la operación de traslado con mantenimiento de la personalidad jurídica y modificación de la lex societatis (con el fin de evitar situaciones claudicantes); b) que se diese cumplimiento a los requisitos establecidos por el derecho nacional del Estado de origen, si bien el Consejo Federal suizo podía incluso autorizar la modificación de estatuto jurídico de la sociedad incluso en aquellos supuestos en los que no cumpliesen los requisitos establecidos por el derecho extranjero (p. ej. en relación con la protección de los derechos de socios minoritarios y acreedores), y c) que la sociedad en cuestión se adaptase a una de las formas societarias propias del derecho suizo (véase arts. 161 y 162 de la Ley Federal de 18 de diciembre de 1987 de Derecho Internacional Privado). Por su parte, el traslado al extranjero de la sede social de una sociedad constituida con arreglo al ordenamiento suizo exigía: a) que se diese cumplimiento a las condiciones establecidas por el propio derecho suizo; b) que la legislación del Estado de destino admitiese la operación de traslado con mantenimiento de la personalidad jurídica, y c) que se informe a los acreedores de la operación y del cambio del estatuto jurídico de la sociedad que esta supone, si bien tratándose de sociedades inscritas en el Registro se exige de forma adicional y antes de proceder a la cancelación de la inscripción registral de la sociedad la acreditación fehaciente de que los acreedores consienten la operación de traslado o que sus créditos han sido debidamente satisfechos o garantizados (véase arts. 163 y 164 de la Ley Federal de 18 de diciembre de 1987 de Derecho Internacional Privado). Sobre esta cuestión, véase Rafael ARENAS GARCÍA, Registro Mercantil y Derecho del comercio internacional, Colegio de Registradores de la Propiedad y Mercantiles de España, Madrid, 2000, pp. 257-259 y 267.

15 Una crítica a la exigencia de convenio prevista en los arts. 149.2 de la LSA y 72.2 de la LSRL puede encontrarse en BLANCO-MORALES LIMONES, op. cit., nota 6, pp. 133-135. A su juicio, el art. 58 del TCEE serviría de base para dar cumpli- 
citado convenio nunca llegó a aprobarse, la viabilidad efectiva de la operación resultaba más teórica que práctica ${ }^{16}$. No obstante, en el caso inverso, y aun en ausencia de cualquier disposición específica al respecto en la LSA o en la LSRL, podría afirmarse que el art. 309 del RRM relativo a la publicidad registral del traslado daba cobertura a la realización de operaciones de transferencia de derecho de la sede social de sociedades extranjeras con mantenimiento de la personalidad jurídica (tal y como muestra la Resolución de la Dirección General de los Registros y del Notariado de 4 de febrero de $2000^{17}$ ), siempre, claro está, que la lex societatis del Estado de origen permitiese la operación en estos términos y la sociedad en cuestión se constituyese bajo una forma societaria propia del ordenamiento español ${ }^{18}$.

miento a este requisito, garantizando el mantenimiento de la personalidad jurídica de la sociedad en el marco de estas operaciones, aunque esta tenga que cambiar de nacionalidad y adaptarse al derecho nacional del Estado miembro de destino. De este modo, el traslado de derecho de la sede social de una sociedad española al extranjero sería posible y quedaría sometido, desde la óptica de nuestro ordenamiento interno, al régimen general previsto para las modificaciones estatutarias. En relación con los aspectos registrales de estas operaciones, recogidos en los arts. 20 y 160 del Real Decreto 1784/1996, de 19 de julio, por el que se aprueba el Reglamento del Registro Mercantil (BOE núm. 184, de 31 de julio de 1996), véase FERNÁNDEZ DEL POZO, op. cit., nota 10, pp. 11906-11908.

16 En este sentido, ARENAS GARCÍA, op. cit., nota 14, pp. 261-262, entendía que el cambio de la lex societatis derivado del traslado transfronterizo de la sede social de una sociedad española conllevaba su disolución. Más flexible se mostraba GARCIMARTÍN ALFÉREZ, op. cit., nota 5, pp. 127 y ss., que distinguía entre dos supuestos: uno ordinario, en el que el traslado transfronterizo del domicilio social determinaba un cambio de la lex societatis, y otro extraordinario (reflejado en el art. 20 del RRM), en el que la operación de traslado no implicaba una modificación de la lex societatis, de forma tal que la exigencia de convenio internacional como requisito para el mantenimiento de la personalidad jurídica solo resultaba exigible en relación con el segundo de los supuestos apuntados. Sobre esta cuestión, y en relación a la división doctrinal existente entre los partidarios y detractores de que estas operaciones de traslado al extranjero de la sede social de sociedades españolas pudiesen efectuarse con mantenimiento de la personalidad jurídica, véase SANCHO VILLA, op. cit., nota 5, pp. 233-234.

17 BOE núm. 55, de 4 de marzo de 2000. Sobre esta resolución, relativa al traslado de la sede social de una sociedad de Liechtenstein a España, véase Diana SANCHO VILLA, «El traslado del domicilio social a España en el Registro Mercantil», Anuario Español de Derecho Internacional Privado, 2000, pp. 465-483.

18 En este sentido, véase GARCIMARTÍN ALFÉREZ, op. cit., nota 5, p. 135; o FERNÁNDEZ DEL POZO, op. cit., nota 10, p. 11891. 
En relación con esta cuestión, no debe perderse de vista que en aquellos supuestos en los que una sociedad constituida con arreglo al derecho nacional de otro Estado establecía en España su principal establecimiento o explotación, estaba obligada, por una parte, a trasladar su domicilio social a nuestro país en virtud de lo establecido en los arts. 5.2 de la LSA y 6.2 de la LSRL ${ }^{19}$, debiendo constituirse como sociedad española ${ }^{20} \mathrm{y}$, por otra parte, a inscribirse en el Registro Mercantil ${ }^{21}$. Ciertamente, la no verificación del cumplimiento de estas obligaciones se traduciría en el no reconocimiento de la sociedad como tal y su calificación como sociedad irregular, resultándole de aplicación el régimen de las sociedades colectivas si su objeto es mercantil ${ }^{22}$. Precisamente por este motivo, algunos autores han destacado como, en este tipo de supuestos, el posterior traslado de la sede social de la sociedad en cuestión desde el Estado miembro de constitución hacia España podría servir para «regularizar» su situación, y evitar los problemas derivados de su no reconocimiento ${ }^{23}$.

Por lo que respecta a los Estados miembros que seguían el modelo de la sede real, cabría señalar que no era infrecuente que sus ordenamientos jurídicos exigiesen a las sociedades cuyo establecimiento principal o sede de administración/dirección efectiva estuviese localizada en su territorio que estableciesen su sede estatutaria dentro del mismo ${ }^{24}$. De este modo, el hecho de que

19 Este requisito se encuentra actualmente previsto en el art. 9.2 del Real Decreto Legislativo $1 / 2010$, de 2 de julio, por el que se aprueba el texto refundido de la Ley de Sociedades de Capital (BOE núm. 161, de 3 de julio de 2010).

20 Una completa explicación del sistema español de atribución de la nacionalidad de las personas jurídicas previsto en el art. 5 de la LSA y en el art. 6 de la LSRL puede encontrarse en FERNÁNDEZ DEL POZO, op. cit., nota 10, pp. 11868-11873.

21 Véase art. 81.1 del RRM.

22 En este sentido, véase Antonio DOMÍNGUEZ PUNTAS, "Nacionalidad, domicilio social, y residencia fiscal de las sociedades mercantiles (III)», Crónica Tributaria, núm. 148, 2003, p. 66; ARENAS GARCÍA, op. cit., nota 14, pp. 136-137; Diana SANCHO VILLA, "La transferencia internacional de la sede social en el comercio internacional», Boletín Económico del ICE, núm. 2674, 2000, p. 7, disponible en: http:// www.revistasice.info/cachepdf/BICE_2674_I-XII_2C2C31EC5222C1968958E8D4D479B139.pdf (consultado por última vez el 9-3-2017), o BLANCO-MORALES LIMONES, op. cit., nota 6, p. 110.

23 Sobre esta cuestión, véase ESTEBAN DE LA ROSA, op. cit., nota 2, p. 76, o FERNÁNDEZ DEL POZO, op. cit., nota 10, p. 11883.

24 En este sentido, véase Rafael ARENAS GARCÍA, «Lex societatis y derecho de establecimiento", en Rafael ARENAS GARCÍA, Carlos GÓRRIZ LÓPEZ y Jorge MIQUEL RODRÍGUEZ (coords.), Autonomía de la voluntad y exigencias imperativas en el derecho internacional de sociedades y otras personas jurídicas, Atelier, Barcelona, 2014, 
la sede social de una sociedad estuviese localizada fuera del Estado miembro en el que tenía su sede real (sede de administración central/sede de dirección efectiva/establecimiento principal) determinaba, con carácter general, el no reconocimiento de la sociedad por parte de dicho Estado (tal y como sucedía, por ejemplo, en Alemania o Bélgica) ${ }^{25}$ lo que, a su vez, se traducía en diferentes consecuencias jurídicas en función de la legislación societaria del Estado miembro en cuestión, pudiendo observarse una tendencia hacía la «degradación» de su tipo social y la aplicación del régimen de la sociedad irregular ${ }^{26}$.

En definitiva, podría afirmarse que, desde el punto de vista de los Estados miembros partidarios del modelo de la sede real, la posibilidad de llevar a cabo un traslado "aislado" de la sede social al extranjero con mantenimiento de la personalidad jurídica debía hacer frente a importantes obstáculos jurídicos que dificultaban en gran medida su viabilidad efectiva ${ }^{27}$. De hecho, en

p. 130. A este respecto, se ha apuntado que el fundamento de esta exigencia se encuentra en la interpretación que dichos Estados miembros realizaban de la obligación impuesta por los arts. 2.1, 3.1 y 3.2 de la Primera Directiva 68/151/CEE del Consejo, de 9 de marzo de 1968, tendente a coordinar, para hacerlas equivalentes, las garantías exigidas en los Estados miembros a las sociedades definidas en el segundo párrafo del art. 58 del Tratado, para proteger los intereses de socios y terceros (DOUE L 65, de 14 de marzo de 1968 , p. 8) y relativa a la necesidad de inscribir los estatutos y la escritura de constitución de las sociedades anónimas en un registro público situado en el lugar de incorporación de la sociedad. Así lo entiende, Federico MUCCIARELLI, "Company 'Emigration' and EC Freedom of Establishment: Daily Mail Revisited", European Business Organization Law Review, vol. 9, núm. 2, 2008, pp. 284-285.

En este sentido, véase SANCHO VILLA, op. cit., nota 5, p. 86. No obstante, y a este respecto, ARENAS GARCÍA, op. cit., nota 24, pp. 220 y 222 ha apuntado que este resultado del no reconocimiento por parte de los Estados miembros seguidores de la teoría de la sede real podría no producirse si el Estado miembro conforme a cuyo derecho nacional fue creada la sociedad siguiese el modelo de la constitución, y siempre que se admita que la constitución de la sociedad «puede regirse por un Derecho y determinados aspectos del régimen societario por otro". Asimismo, no puede perderse de vista que el posterior traslado de la sede social de la sociedad en cuestión al Estado miembro donde se encontraba localizada su sede de administración central o principal establecimiento podría abrir la puerta a que esta fuese reconocida ex novo como una sociedad regular propia de dicho Estado miembro (en este sentido, véase GARCIMARTÍN ALFÉREZ, op. cit., nota 5, p. 112).

26 En este sentido, véase SANCHO VILLA, op. cit., nota 5, p. 136.

27 A este respecto, y sin ánimo de entrar en profundidad en esta cuestión, cabría señalar como en este tipo de Estados miembros, el mero traslado de la sede de administración central o dirección efectiva de la sociedad (sede real) tampoco estaba exento de dificultades desde la óptica del mantenimiento de la personalidad jurídica en la medida 
Alemania, si una sociedad constituida con arreglo al derecho alemán trasladaba al extranjero su sede social manteniendo localizada su sede real en el territorio de dicho Estado miembro, la doctrina científica se encontraba divida con respecto a cuáles serían las consecuencias materiales de la operación: para un sector mayoritario de la doctrina, el acuerdo de traslado sería nulo ya que las sociedades constituidas en Alemania deben tener su sede social en Alemania, mientras que para otros autores la operación determinada la disolución de la sociedad, no siendo inscribible, en ningún caso, el acuerdo de traslado en el Registro alemán ${ }^{28}$. Siguiendo una línea similar, en Austria la mayoría de la doctrina científica también era de la opinión de que este tipo de operaciones de traslado transfronterizo de la sede social llevadas a cabo por parte

en que se alteraba el punto de conexión establecido por las normas de conflicto del Estado miembro de origen dando lugar a una modificación de la lex societatis (transferencia de derecho). Así, y a título de ejemplo, podría traerse a colación el caso de Alemania, donde el traslado de la sede real de una sociedad constituida de acuerdo con el ordenamiento jurídico alemán a otro Estado miembro conllevaba la disolución de la sociedad (en este sentido, véase GARCIMARTÍN ALFÉREZ, op. cit., nota 6, p. 651). No obstante, lo cierto es que también pueden encontrarse Estados miembros representantes del modelo de la sede real que contaban con disposiciones específicas en sus ordenamientos destinadas a posibilitar la realización de estas operaciones con mantenimiento de la personalidad jurídica, tal y como sucede con Portugal, donde el art. 3.5 del Decreto-Lei núm. 262/86, de 2 de septiembre por el que se aprueba el Código das Sociedades Comerciais establece que «a sociedade que tenha sede efectiva em Portugal pode transferi-la para outro país, mantendo a sua personalidade jurídica, se a lei desse país nisso convier». En este sentido, podría apuntarse que más allá de la necesidad de que el Estado de destino deba admitir también la posibilidad de que la sociedad en cuestión conserve su personalidad jurídica como resultado de la operación, la ley portuguesa exige que la aprobación del acuerdo de traslado se someta a los mismos requisitos que rigen para las modificaciones estatutarias, de forma tal que la decisión de traslado en ningún caso podrá ser adoptada por una mayoría inferior al $75 \%$ de los votos representativos del capital social, concediéndose un derecho de separación a aquellos socios que no hubiesen votado en favor del mismo. Por el contrario, ningún tipo de derecho específico se reconocía a los acreedores de la sociedad en el marco de estas operaciones (véase art. 3.6 del citado código). Asimismo, y en la situación inversa, también se contempla, sujeto al requisito de adaptación del estatuto social a las leyes portuguesas, el mantenimiento de la personalidad jurídica de la sociedad extranjera que traslada su sede efectiva a Portugal al disponer el art. 3.2 del citado Código das Sociedades Comerciais que «a sociedade que transfira a sua sede efectiva para Portugal mantém a personalidade jurídica, se a lei pela qual se regia nisso convier, mas deve conformar com a lei portuguesa o respectivo contrato social».

Sobre esta cuestión, véase GARCIMARTÍN ALFÉREZ, op. cit. nota 5, p. 111. 
de sociedades constituidas de acuerdo con el derecho austríaco conllevaba su disolución ${ }^{29}$.

Por lo que respecta al supuesto inverso, es decir, el traslado de la sede social de una sociedad constituida con arreglo a un ordenamiento extranjero a uno de estos Estados miembros, parece que, con carácter general, requería la disolución de la sociedad en su Estado miembros de origen y su posterior reconstitución con arreglo al derecho nacional alemán ${ }^{30}$, si bien es cierto que un sector de la doctrina defendía la posibilidad de llevar a cabo estas operaciones con mantenimiento de la personalidad jurídica siempre que, por una parte, la sociedad extranjera pudiera acomodarse a alguna de las formas societarias previstas por el ordenamiento jurídico del Estado miembro de acogida, adaptando sus estatutos al derecho nacional de dicho Estado y, por otra parte, que la legislación doméstica del Estado miembro de origen admita la posibilidad de realizar la operación de traslado con mantenimiento de la personalidad jurídica $^{31}$.

No obstante, en otros Estados miembros como Francia, el traslado transfronterizo de la sede social al extranjero con mantenimiento de la personalidad jurídica y modificación de la lex societatis de las sociedades anónimas resultaba posible siempre que el Estado miembro de acogida hubiese suscrito con Francia un convenio donde se contemplase tal posibilidad ${ }^{32}$. A este respecto, cabría señalar como la falta de convenios de esta naturaleza firmados por Francia, determinaba que, al igual que sucedía en el caso de España, esta posibilidad fuese más teórica que práctica, si bien es cierto que un sector de la doctrina, sobre la base de lo establecido en los arts. 31 y 60 de la Ley 66/537 de 24 de julio de 1966 sobre las Sociedades Comerciales ${ }^{33}$, defendía la posibi-

29 En este sentido, véase SANCHO VILLA, op. cit., nota 5, p. 227.

30 En este sentido, véase SANCHO VILLA, op. cit., nota 5, pp. 287-288.

31 Sobre esta cuestión, véase ARENAS GARCÍA, op. cit., nota 24, p. 253.

32 En este sentido, y en relación con las sociedades anónimas, véase art. 154 de la Ley 66/537 de 24 de julio de 1966 sobre las Sociedades Comerciales (JORF de 26 de julio de 1966), cuyo tenor literal se encuentra recogido actualmente en el art. L225-97 del Code de Commerce francés.

33 Nótese como estos preceptos, cuyo contenido se encuentra plasmado actualmente en los arts. L226-1 y L223-30 del Code de Commerce francés, hacían referencia, respectivamente, a la posibilidad de que las sociedades comanditarias por acciones y las sociedades de responsabilidad limitada francesas pudiesen cambiar su nacionalidad en virtud del acuerdo unánime de sus socios. 
lidad de llevar a cabo estas operaciones con mantenimiento de la personalidad jurídica siempre que el acuerdo de traslado fuese adoptado por unanimidad ${ }^{34}$.

En el supuesto inverso, las Réponses Ministérielles de 19 de febrero de $1972^{35}$ y de 26 de enero de $1987^{36}$ entendían que la inexistencia de disposiciones normativas específicas sobre la acogida de la sede social y transformación en una forma societaria francesa de una sociedad constituida de acuerdo con la legislación de otro Estado miembro, debía interpretarse como una negativa general a la realización de estas operaciones de traslado transfronterizo del domicilio social con mantenimiento de la personalidad jurídica ${ }^{37}$. Sin embargo, lo cierto es que la doctrina mayoritaria entendía que el traslado de la sede social a Francia por parte de una sociedad extranjera no determinaba per se la pérdida de su personalidad jurídica, siempre que así lo permitiera la legislación del Estado miembro de origen y la sociedad adaptase sus estatutos a lo establecido en el ordenamiento jurídico francés ${ }^{38}$.

En síntesis, y haciendo abstracción de toda la jurisprudencia del Tribunal de Justicia de la Unión Europea (TJUE) en materia de libertad de establecimiento surgida desde comienzos del nuevo milenio en relación con el traslado transfronterizo de la sede social, así como de la aprobación del Reglamento (CE) 2157/2001 relativo a la Sociedad Europea ${ }^{39}$, podría afirmarse que uno de los principales obstáculos que se planteaban a la realización de estas operaciones con cambio de lex societatis (transferencia de derecho) ${ }^{40}$ pivotaba sobre

34 Sobre esta cuestión véase WYMEERSCH, op. cit., nota 12, p. 11, y SANCHO VILLA, op. cit., nota 5, p. 230. action militante pour pallier la carence de la Commission européenne!», Semaine Juridique (Édition Générale), núm 41, 2012, p. 1840.

38 En este sentido, véase BLANCO-MORALES LIMONES, op. cit., nota 6, pp. 84-85.

39 Reglamento (CE) núm. 2157/2001 del Consejo, de 8 de octubre de 2001, por el que se aprueba el Estatuto de la Sociedad Anónima Europea (DOCE L 294, de 10 de noviembre de 2001, p. 1).

40 Nótese como a lo largo de este trabajo nos estamos centrando en la problemática que planteaban las operaciones de traslado transfronterizo de la sede social que determinaban una modificación de la lex societatis por ser las que mayores inconvenientes presentaban desde el punto de vista práctico. Por lo que respecta a las denominadas "transferencias de hecho» (traslado transfronterizo de la sede social sin cambio de la ley aplicable), que tampoco estaban exentas de cuestiones conflictivas, nos remitimos al completo análisis realizado por SANCHO VILLA, op. cit., nota 5, pp. 250-271. 
el mantenimiento de la personalidad jurídica de la sociedad en cuestión en el marco de las mismas ${ }^{41}$. Ciertamente, el hecho de que la sociedad tuviera que disolverse y liquidarse en el Estado miembro de origen y, posteriormente, reconstituirse en el Estado miembro de destino para completar la operación de traslado, se traducía no solo en elevados costes ${ }^{42}$, sino también en la aparición de importantes obstáculos administrativos, así como de la problemática relativa a la protección de los derechos de los accionistas minoritarios, acreedores, y trabajadores de la sociedad.

A este respecto, no puede perderse de vista que, aun cuando algunos Estados miembros disponían de normas en sus respectivas legislaciones domésticas que posibilitaban su realización, lo cierto es que su viabilidad efectiva quedaba comprometida en muchas ocasiones por un marco jurídico insuficiente, no solo en el plano del derecho societario, sino también en el ámbito del derecho registral, que impedía que la operación de traslado pudiera llevarse a cabo con las debidas garantías de seguridad jurídica y protección adecuada

41 Sobre esta cuestión, véase el documento de trabajo de la Comisión Europea «Impact assessment on the Directive on the cross-border transfer of registered office», SEC (2007) 1707, 12-12-2007, pp. 9-10; Frans VANISTENDAEL, «Taxation of corporate reorganizations», en Victor THURONYI (ed.), Tax Law Design and Drafting, vol.2, International Monetary Fund, Washington, 1998, p. 900; u Odette LOY, «La troisième directive du Conseil des Communautés européennes du 9 octobre 1978 concernant les fusions des sociétés anonymes», Revue trimestrielle de droit européenne, núm. 2, 1980, pp. 354-355.

En primer lugar, tendríamos todos los gastos directos asociados a los trámites y procedimientos necesarios para completar la operación. Dichos gastos resultan particularmente elevados por lo que respecta a la liquidación de la sociedad, dependiendo de factores tales como el patrimonio de la sociedad, el número de acreedores o la remuneración del profesional encargado de llevarla a cabo. A esto tendríamos que añadir el coste financiero que supone para la sociedad, por una parte, al tener que dar cumplimiento a las obligaciones contraídas con sus acreedores antes de la fecha acordada y, por otra, la imposibilidad de utilizar sus activos durante el periodo de liquidación, aspecto este último que también tendrá repercusiones negativas para la empresa a nivel económico y/o comercial. En segundo lugar, desde el punto de vista fiscal, la disolución y liquidación de la sociedad daría lugar, con carácter general, al gravamen de las plusvalías derivadas del incremento de valor de los elementos patrimoniales de la sociedad, así como a la pérdida de los beneficios o incentivos fiscales cuya titularidad ostentaba la sociedad que se liquida en el Estado miembro de origen. Sobre esta cuestión, véase el documento de trabajo de la Comisión Europea «Impact assessment on the Directive on the cross-border transfer of registered office», SEC (2007) 1707, 12-12-2007, pp. 40-41). 
de los derechos de los colectivos afectados por la misma (socios minoritarios, acreedores, y trabajadores).

Por otra parte, la adaptación de los estatutos sociales al derecho nacional del Estado miembro de destino por parte de la sociedad que trasladaba su sede social desde otro Estado miembro tampoco estaba exenta de aspectos problemáticos habida cuenta de las diferencias originarias entre las legislaciones domésticas de los diferentes Estados miembros con respecto a los requisitos y condiciones que debían verificar sus formas societarias nacionales; no obstante, y como bien han señalado algunos autores ${ }^{43}$, el avance del proceso de armonización en materia de derecho societario llevado a cabo por el legislador europeo ha contribuido de forma decisiva a reducir las dificultades existentes en este ámbito ${ }^{44}$.

A nuestro juicio, la reticencia natural de los Estados miembros a permitir estas operaciones de traslado transfronterizo de la sede social no resulta infundada si tenemos presente que, como resultado de las mismas, podía producirse un pérdida del "control jurídico" de las sociedades constituidas con arreglo a su derecho nacional (al quedar estas sometidas al ordenamiento jurídico del Estado miembro de destino), aun cuando la actividad económica de las mismas permaneciese en su territorio ${ }^{45}$; así como, en determinados casos, la pérdida de la capacidad de gravar sus beneficios, habida cuenta de que la localización del domicilio social constituye uno de los criterios empleados para determinar la residencia fiscal de la sociedad y, por ende, su sujeción al impuesto sobre sociedades nacional.

Ahora bien, en relación con este último aspecto, es importante tener presente que, en la medida en que el concepto de «residencia fiscal» no se encuentra armonizado a nivel europeo, lo cierto es que aun cuando el traslado del domicilio social puede determinar que el Estado miembro de acogida considere a la sociedad como residente fiscal en su territorio, el Estado miembro de origen podría hacer lo propio empleando otros criterios de conexión con-

43 Véase SANCHO VILLA, op. cit., nota 22, pp. 9-10.

44 A título de ejemplo, podría traerse a colación la Segunda Directiva 77/91/CEE del Consejo, de 13 de diciembre de 1976, tendente a coordinar, para hacerlas equivalentes, las garantías exigidas en los Estados miembros a las sociedades definidas en el segundo párrafo del art. 58 del Tratado, para proteger los intereses de socios y terceros, en lo relativo a la constitución de la sociedad anónima, así como al mantenimiento y modificaciones de su capital (DOCE L 26, de 31 de enero de 1977, p. 1).

45 En este sentido, véase Catherine CATHIARD, «European Added Value Assessment on a Directive on the cross-border transfer of company seats (14th company law Directive). Legal effects of the requested legislative instrument", Research paper by Jeantet Associés Aarpi, 2012, p. 75. 
templados en su legislación doméstica como, por ejemplo, la sede de dirección de efectiva de la sociedad ${ }^{46}$. De este modo, se produciría un supuesto de doble residencia fiscal que, en la mayoría de los casos y siguiendo lo establecido en el art. 4.3 del Modelo de Convenio OCDE, se resolvería en favor del Estado miembro donde radicase su sede de dirección efectiva (place of effective management). Por ello, parece que el verdadero riesgo para los derechos de gravamen del Estado miembro de origen se producirá en aquellos supuestos en los que la sociedad en cuestión traslade no solo su sede social, sino también su sede real al Estado miembro de destino.

Por último, cabría señalar que la falta de un acuerdo entre los Estados miembros para garantizar vía convenio el mantenimiento de la personalidad jurídica de la sociedad en el marco de estas operaciones, siguiendo las exigencias del antiguo art. 220 TCEE (hoy eliminado del TFUE), unida a la ausencia de una respuesta a esta problemática desde el plano derecho positivo europeo, ha determinado que los únicos avances al respecto hayan venido de la mano de la jurisprudencia del TJUE en el ámbito de la libertad de establecimiento $^{47}$, destacando por su importancia las conclusiones derivadas de las sentencias dictadas en los asuntos SEVIC Systems $(2005)^{48}$, Cartesio $(2008)^{49}$ y VALE Épitési $(2012)^{50}$. En este sentido, no puede perderse de vista que las

46 A este respecto, algunos autores han apuntado que la armonización y coordinación de los factores de conexión que determinan la residencia fiscal sigue constituyendo un auténtico reto para el legislador europeo, de forma tal que, mientras sigan siendo las legislaciones nacionales de los Estados miembros las encargadas de su definición, existirá el riesgo de que se produzca una suerte de «vínculo interminable» (never-ending link) entre las sociedades y las diferentes jurisdicciones fiscales que limite las posibilidades de que estas puedan trasladar su sede (social o real) sin tener que afrontar consecuencias fiscales adversas (véase Elena GONZÁLEZ SÁNCHEZ y Juan FRANCH FLUXÀ, «The transfer of the seat of and the freedom of establishment for companies in the European Union: an analysis of ECJ case law and the regulation on the statute for a European Company», European Taxation, vol. 45, núm. 6, 2005, p. 221).

Sobre la importancia de la libertad de establecimiento para la construcción del mercado único, véase, entre otros, Alfonso Luis CALVO CARAVACA y Javier CARRASCOSA GONZÁLEZ, Mercado único y libre competencia en la Unión Europea, Colex, Madrid, 2003, pp. 87-200.

48 Sentencia del TJUE de 13 de diciembre de 2005, SEVIC Systems AG, C-411/03, EU:C:2005:762.

49 Sentencia del TJUE de 16 de diciembre de 2008, Cartesio Oktató és Szolgáltató bt, C-210/06, EU:C:2008:723.

50 Sentencia del TJUE de 12 de julio de 2012, VALE Építési Kft, C-378/10, E:C:2012: 440 . 
disposiciones del art. 49 del TFUE se proyectan plenamente sobre el «derecho de establecimiento secundario" (apertura de agencias, sucursales o filiales en el territorio de otro Estado miembro ${ }^{51}$ y de forma parcial sobre el «derecho de establecimiento primario", habida cuenta de que el Tratado solo da cobertura explícita a la constitución y gestión de empresas y, especialmente, de sociedades (tal como se definen en el párrafo segundo del art. 54 del TFUE) en el territorio de otro Estado miembro y en las condiciones fijadas por la legislación de dicho Estado para sus propios nacionales ${ }^{52}$, pero no a otras manifestaciones del mismo tales como el traslado transfronterizo del domicilio social con mantenimiento de la personalidad jurídica; de ahí que, en relación con estas operaciones, la labor interpretativa del TJUE haya adquirido una dimensión si cabe más relevante ${ }^{53}$.

\section{LAS LIMITACIONES DE LA JURISPRUDENCIA DEL TJUE EN RELACIÓN CON EL TRASLADO TRANSFRONTERIZO DE LA SEDE SOCIAL, ASÍ COMO DEL USO DE «VÍAS INDIRECTAS» PARA LLEVAR A CABO ESTAS OPERACIONES}

Sin lugar a dudas, la jurisprudencia del TJUE en materia de libertad de establecimiento ha contribuido de forma decisiva, por una parte, a la eliminación de alguno de los obstáculos jurídicos que afectaban al traslado transfronterizo de la sede social y, por otra, a la delimitación de las facultades de los Estados miembros a la hora de imponer requisitos y condiciones a

51 Véase art. 49 del TFUE, párrafo primero; y, en el mismo sentido, art. 50.2 del TFUE, apartado f).

52 Véase art. 49 del TFUE, párrafo segundo.

53 En este sentido, se ha afirmado que «la facultad de trasladar la sede social de una sociedad de un Estado miembro a otro es el corolario lógico de la libertad de establecimiento garantizada por los arts. 49 y 54 del Tratado. Sin embargo, el principio de la libertad de establecimiento previsto por el Tratado no permite en la práctica que una sociedad pueda trasladarse desde su Estado miembro de origen a otro Estado miembro manteniendo su personalidad jurídica» (véase CATHIARD, op. cit., nota 45, p. 21). En un sentido similar, véase Francisco MARTÍNEZ RIVAS, «Traslado internacional de sede social en la Unión Europea: del caso Daily Mail al caso Cartesio. Veinte años no son nada», Cuadernos de Derecho Transnacional, vol. 1, núm. 1, 2009, p. 138, y Servaas VAN THIEL, «La supresión de la discriminación en materia de imposición sobre la renta como barrera a la libre circulación de personas en la Unión Europea», Quincena Fiscal, núm.12, 1996, p. 45. 
su realización ${ }^{54}$. A este respecto, y con carácter previo, debemos partir de la distinción entre dos supuestos bien diferenciados, a saber: a) el traslado de la sede social de una sociedad constituida según el ordenamiento interno de un Estado miembro a otro Estado miembro sin cambio del derecho por el que se rige, y 2) el traslado de la sede social de una sociedad creada de acuerdo con la legislación de un Estado miembro a otro Estado miembro con cambio del derecho nacional aplicable, a través de la transformación de la sociedad en una forma societaria regulada por la legislación doméstica del Estado miembro de destino.

De este modo, en el primero de los supuestos apuntados, la facultad reconocida en la sentencia Cartesio a los Estados miembros de definir los criterios de conexión exigidos para que una sociedad pueda considerarse constituida con arreglo a su derecho nacional y mantenga posteriormente tal condición, se traduce en que el Estado miembro de origen podrá impedir que una sociedad que pretende trasladar su domicilio social conserve su personalidad jurídica originaria, en la medida en que dicha operación suponga la ruptura del vínculo de conexión establecido por su ordenamiento interno ${ }^{55}$. Esto obligaría a la sociedad en cuestión a disolverse y liquidarse en el Estado miembro de origen y reconstituirse en el Estado miembro de destino.

Ahora bien, en el supuesto de que el traslado de la sede social se instrumente a través de una operación de transformación transfronteriza con cambio del derecho nacional aplicable, el TJUE ha dejado claro que la facultad de definir los criterios de conexión anteriormente mencionada no puede justificar que el Estado miembro de origen imponga la disolución y liquidación de una sociedad constituida de acuerdo con su legislación doméstica al objeto de impedir su transformación en una forma societaria propia del derecho nacional del Estado miembro al que la sociedad pretende trasladar su domicilio social, siempre que el ordenamiento de este último Estado admita tal posibilidad. De este modo, una restricción de tal naturaleza a la libertad de establecimiento de la sociedad en cuestión solo resultaría admisible si es-

54 Nótese como en el ámbito del traslado transfronterizo de la sede real, el TJUE ya había tenido ocasión de eliminar alguno de los obstáculos jurídicos que impactaban negativamente sobre la realización de estas operaciones e imponer límites a las facultades de los Estados miembros de origen y de destino a través de sus sentencias de 9 de marzo de 1999, Centros, C-212/97, EU:C:1999:126; de 5 de noviembre de 2002, Überseering BV, C-208/00, EU:C:2002:632, y de 30 de septiembre de 2003, Inspire Art Ltd, C-167/01, EU:C:2003:512.

55 Véase Sentencia del TJUE de 16 de diciembre de 2008, Cartesio Oktató és Szolgáltató bt, C-210/06, EU:C:2008:723, apartado 110. 
tuviera justificada por razones imperiosas de interés general y se respetase el principio de proporcionalidad ${ }^{56}$.

No obstante, en relación con esta cuestión, podrían plantearse problemas en aquellos supuestos en los que las normas de conflicto del Estado miembro de destino remiten a la legislación del Estado miembro de origen para determinar si el traslado transfronterizo del domicilio social con mantenimiento de la personalidad jurídica resulta posible y esta optase por el modelo de la incorporación, exigiendo la disolución y liquidación de la sociedad, o bien en aquellos supuestos en los que la legislación del Estado miembro de destino supedita la validez de la operación a la emisión de una autorización o cualquier otro tipo de certificado sujeto a condiciones por parte de las autoridades del Estado Miembro de origen. Ciertamente, si tenemos en cuenta que la sentencia VALE Épitési impide al Estado miembro de destino oponerse a la realización de una transformación transfronteriza si admite tal posibilidad en el ámbito doméstico, parece que tanto la remisión al derecho nacional del Estado miembro de origen para determinar si la operación resulta posible como la supeditación de su validez a la emisión de una autorización o certificado por parte de las autoridades nacionales de dicho Estado miembro, constituiría una restricción de la libertad de establecimiento que solo resultaría admisible si existiesen razones imperiosas de interés general y se superase el test de proporcionalidad, de acuerdo con lo establecido en la jurisprudencia del TJUE ${ }^{57}$.

Por su parte, y partiendo de la base de que las operaciones de transformación de sociedades (cross-border conversion) constituyen una modalidad particular de ejercicio de la libertad de establecimiento prevista en el Tratado ${ }^{58}$, el

56 Véase Sentencia del TJUE de 16 de diciembre de 2008, Cartesio Oktató és Szolgáltató bt, C-210/06, EU:C:2008:723, apartados 112-113.

57 En una línea similar, pero con anterioridad a la sentencia VALE Építési, ya se había posicionado Stefan LIEBLE, «El traslado transfronterizo del domicilio social y la libertad de establecimiento», en Rafael ARENAS GARCÍA, Carlos GÓRRIZ LÓPEZ y Jorge MIQUEL RODRÍGUEZ, (coords.), La internacionalización del Derecho de sociedades, Atelier, Barcelona, 2010, pp. 119-120.

58 Esta idea ya había sido apuntada en la Sentencia del TJUE de 13 de diciembre de 2005, SEVIC Systems AG, C-411/03, EU:C:2005:762, apartado 19. A este respecto, se ha apuntado que la STJUE en el asunto Cartesio (apartados 111-113) emplea el término "conversión" de una forma un poco ambigua, y no deja claro si dicho concepto debe entenderse de una forma restrictiva, esto es, como el cambio de un tipo societario propio de un ordenamiento en su «equivalente funcional» en el ordenamiento de otro Estado miembro (sociedad anónima española en una $\mathrm{GmbH}$ alemana); o de una forma amplia que permita cualquier tipo de cambio en la forma jurídica de la sociedad (sociedad anónima española en un part- 
Estado miembro de destino no podrá otorgar un tratamiento discriminatorio a las transformaciones internas y a las transformaciones transfronterizas, en el sentido de que si su derecho nacional prevé para las sociedades nacionales la facultad de transformarse, no podrá denegar, con carácter general, la posibilidad de que una sociedad constituida de acuerdo con la legislación de otro Estado miembro se transforme en una forma societaria propia de su ordenamiento ${ }^{59}$. Ahora bien, en la medida en que como resultado de la transformación transfronteriza surgirá una nueva sociedad en el Estado miembro de destino creada con arreglo a su Derecho nacional, dicho Estado podrá exigir el cumplimiento de los requisitos contemplados en su ordenamiento por lo que respecta a la constitución y funcionamiento de una sociedad, pero

nership inglés), tal y cómo permiten algunos Estados miembro como Alemania (Umwandlungsgesetz [Reorganisation of Companies Act], sección 191(2). Sobre esta cuestión, véase Carsten GERNER-BEUERLE y Michael SCHILLIG, "The mysteries of freedom of establishment after Cartesio", International and comparative law quarterly, vol. 59, núm. 2, 2010, pp. 319-320, o Andrzej WISNIEWSKI y Adam OPALSKI, "Companies' Freedom of Establishment after the ECJ Cartesio Judgment", European Business Organization Law Review, vol. 10, núm. 4, 2009, pp. 615-617.

59 Véase Sentencia del TJUE de 12 de julio de 2012, VALE Építési Kft, C-378/10, EU:C:2012:440, apartado 41. A este respecto, no puede perderse de vista que tal diferencia de trato en función de la naturaleza interna o transfronteriza de la operación de transformación por parte del Estado miembro de destino podría disuadir a las sociedades constituidas de acuerdo con la legislación de otro Estado miembro de ejercer su derecho de establecimiento garantizado por el Tratado, introduciendo una restricción a dicha libertad fundamental que no encontraría justificación ni en la inexistencia de normas de derecho derivado de la UE, ni en razones imperiosas de interés general tales como la protección de los intereses de ciertos colectivos (acreedores, socios minoritarios y trabajadores), la preservación de la eficacia de los controles fiscales, o la lealtad de las transacciones comerciales, por cuanto una normativa nacional que impone la denegación general y sistemática de las operaciones de transformación transfronteriza, aun cuando determinados intereses no se encuentren amenazados, va más allá de lo necesario para alcanzar sus objetivos. No obstante, en todo caso deberá verificarse la existencia de una "implantación real» de la sociedad en el Estado miembro de destino ya que, de lo contrario, nos encontraríamos ante un «montaje puramente artificial» (wholly artificial arrangement) que justificaría la adopción de medidas restrictivas de la libertad de establecimiento con fines antiabuso por parte del Estado miembro en cuestión (véase Sentencias del TJUE de 12 de julio de 2012, VALE Építési Kft, C-378/10, EU:C:2012:440, apartados 34-40; y de 12 de septiembre de 2006, Cadbury Schweppes plc, C-196/04, EU:C:2006:544, apartados 65-75). 
siempre desde el debido respeto a los límites derivados de la aplicación de los principios de equivalencia y efectividad ${ }^{60}$.

En cualquier caso, y aun cuando debe reconocerse la importancia de la jurisprudencia del TJUE en materia de libertad de establecimiento al objeto de facilitar el traslado transfronterizo del domicilio social sin liquidación de la sociedad en su Estado miembro de origen (plasmada, a nivel doméstico, en la Sentencia del Oberlandesgericht Nürnberg - Tribunal Superior Regional de Núremberg- de 19 de junio de 2013, 12 W 520/13 ${ }^{61}$, o en la Sentencia del Kammergericht Berlin - Tribunal Superior Regional de Berlín- de 21 de

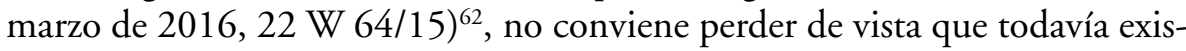
ten cuestiones vinculadas a estas operaciones que presentan contornos difusos (p.ej. la propia aplicación de los principios de equivalencia y efectividad) ${ }^{63} \mathrm{y}$

60 Véase Sentencia del TJUE de 12 de julio de 2012, VALE Építési Kft, C-378/10, EU:C:2012:440, apartados 48-52.

61 Esta resolución judicial admitió la validez bajo el ordenamiento jurídico alemán del traslado transfronterizo del domicilio social de una sociedad de responsabilidad limitada constituida con arreglo a la legislación luxemburguesa y con sede social en dicho Estado miembro, desde Luxemburgo a Alemania, a través de la transformación en una sociedad de responsabilidad limitada constituida bajo la legislación alemana. De este modo, y aun cuando la sociedad luxemburguesa que, como resultado de la operación, pasó a quedar sujeta al ordenamiento alemán, tuvo que modificar su nombre corporativo así como determinados artículos de sus estatutos, el traslado transfronterizo del domicilio social no dio lugar a la liquidación de la sociedad en Luxemburgo, sino que simplemente fue dada de baja del Registro una vez completada la operación. Un análisis más en profundidad de este caso puede encontrarse en Fleur PROP y Felix FELLEISEN, «Cross-Border Transfer of the Registered Office. Yet Another Attempt or a Breakthrough?», Deloitte Tax News, 22-09-2014, disponible en: http://www.deloittetax-news.de/german-tax-legal-news/cross-border-transfer-of-the-registered-office-yetanother-attempt-or-a-breakthrough.html (consultado por última vez el 8-2-2017).

62 Siguiendo la línea de la resolución judicial anteriormente citada, en este caso se admitió el traslado del domicilio social desde París a Berlín por parte de una sociedad de responsabilidad limitada francesa a través de una operación de transformación transfronteriza en una sociedad de responsabilidad limitada alemana. En este sentido, véase Ernst and Young, "Cross-border transformation of a French SARL into a German GmbH», German Tax and Legal Quarterly, núm. 3, 2016, p. 15, disponible en: http:// www.ey.com/Publication/vwLUAssets/2016_EY_GTLQ_Q3/\$FILE/EY_GTLQ_Issue-3_2016.pdf (consultado por última vez el 8-2-2017).

63 A este respecto, algunos autores también han apuntado que las sociedades que trasladan su sede social a otro Estado miembro adoptando una de las formas societarias propias de dicho Estado, quedan necesariamente sujetas, como resultado de la operación, a un conflicto móvil derivado de la modificación del punto de conexión jurídico. De 
que aconsejan abordar la regulación del traslado transfronterizo del domicilio social a través de normas de derecho positivo europeo.

A este respecto, se ha venido apuntando que el marco actual en el que se desarrollan estas operaciones no proporciona una protección adecuada a los accionistas minoritarios, trabajadores, y acreedores ${ }^{64}$, o que la jurisprudencia del TJUE no profundiza en algunos aspectos relevantes de las operaciones de transformación transfronteriza, tales como el momento preciso en el que se produce la ruptura del vínculo de conexión de la sociedad con el Estado miembro de origen y surge el vínculo de conexión con el Estado miembro de destino, o el momento a partir del cual a la sociedad deja de estar sujeta a la legislación del Estado miembro de origen y queda sujeta a la legislación del Estado miembro de destino (p.ej. inscripción en el Registro del Estado miembro de destino y baja en el Registro del Estado miembro de origen) ${ }^{65}$. En este sentido, es importante tener presente que no es labor del TJUE establecer un marco general de naturaleza jurídico-procedimental para la realización de estas operaciones, habida cuenta de que, por una parte, su ámbito de actuación pivota sobre supuestos fácticos concretos y, por otra parte, la interpretación de sus decisiones por los Estados miembros no tiene por qué ser totalmente uniforme, sino que está sujeta a un cierto margen de discrecionalidad ${ }^{66}$.

Por otra parte, y más allá de las limitaciones propias de la jurisprudencia del TJUE en esta materia, cabría señalar que, aun cuando todavía no ha visto la luz una norma de derecho de la UE específicamente referida al traslado transfronterizo del domicilio social, la aprobación de otras normas europeas

este modo, la «salida» del Estado de origen deberá efectuarse según las condiciones previstas por el ordenamiento de dicho Estado, mientras que la «acogida» de la sede social y la adquisición de una nueva forma societaria en el Estado miembro de destino deberá ajustarse a lo establecido en el derecho nacional de este último (véase MENJUCQ, op. cit., nota 37, pp. 1838-1840).

64 Véase COMISIÓN EUROPEA, «Feedback statement. Summary of responses to the public consultation on cross-border transfers of registered offices of companies», septiembre 2013, pp. 11-12.

Sobre esta cuestión, véase Beata WEGRZYNOWSKA, «Cartesio: Analysis of the Case», European Journal of Legal Studies, vol. 2, núm. 2, 2009, pp. 74-75.

66 A este respecto, se ha apuntado que la Comisión podría haber cedido la iniciativa armonizadora en este ámbito al TJUE de forma consciente (aunque sin reconocerlo explícitamente), sabedora de la tradicional problemática que plantea la adopción de acuerdos entre los Estados miembros para la aprobación de normas de derecho europeo en materia societaria (en este sentido, véase Justin BORG-BARTHET, «European private international law of companies after Cartesio", International and Comparative Law Quarterly, vol. 58, núm. 4, 2009, p. 1028). 
en el ámbito societario ha abierto la puerta a nuevas posibilidades para la realización de dichas operaciones. Así, desde la entrada en vigor del Reglamento (CE) 2157/2001, las sociedades anónimas de los distintos Estados miembros tienen la opción de transformarse en una sociedad europea ${ }^{67}$ como paso previo al traslado de su domicilio social a otro Estado miembro, quedando garantizada de este modo la continuidad de la personalidad jurídica, los derechos de trabajadores, accionistas y acreedores ${ }^{68}$, así como el carácter fiscalmente neutro de la operación (siempre que se de cumplimiento a lo establecido en los arts. 12 a 14 de la Directiva 2009/133/CE ${ }^{69}$ ). Con carácter adicional, y en caso de que la forma societaria europea no se adaptase a las necesidades de la empresa en cuestión, siempre existiría la posibilidad de que la sociedad europea se «reconvierta» en una sociedad anónima sujeta al ordenamiento jurídico del Estado miembro de destino ${ }^{70}$.

Sin embargo, lo cierto es que la societas europaea nunca llegó a tener el impacto deseado entre las empresas europeas, de forma tal que su utilidad como instrumento a través del cual articular un traslado transfronterizo del domicilio social ha tenido más relevancia desde el plano teórico que desde el punto de vista práctico ${ }^{71}$. En este sentido, y de forma sucinta, cabría señalar cómo, más allá del restrictivo régimen jurídico propio de la sociedad europea, existen una serie de cuestiones que vendrían a limitar el atractivo de una operación ya de por sí encorsetada en el estricto régimen del art. 8 del Reglamento (CE) 2157/2001, a saber ${ }^{72}$ : la posibilidad de que el Estado miembro de

67 Véase art. 37 del Reglamento (CE) 2157/2001.

68 Véase art. 8 del Reglamento (CE) 2157/2001.

69 Directiva 2009/133/CE, de 19 de octubre de 2009, relativa al régimen fiscal común aplicable a las fusiones, escisiones, escisiones parciales, aportaciones de activos y canjes de acciones realizados entre sociedades de diferentes Estados miembros y al traslado del domicilio social de una SE o una SCE de un Estado miembro a otro (DOUE L 310, de 25 de noviembre de 2009, p. 34).

70 Véase art. 66 del Reglamento (CE) 2157/2001.

71 En este sentido, conviene recordar que entre los años 2004 y 2014 tan solo el $4 \%$ de las sociedades europeas registradas en la Unión Europea y en el Espacio Económico Europeo llevó a cabo una operación de traslado transfronterizo del domicilio social (véase Anders CARLSON, Melinda KELEMEN y Michael STOLLT, Overview of current state of SE founding in Europe, European Trade Union Institute, Brussels, March 2014, p. 10).

72 Una lista más detallada de estos aspectos problemáticos puede encontrarse en COMISIÓN EUROPEA, "Synthesis on the comments on the consultation document of the Internal Market and Services Directorate-General on the results of the study on the operation and the impacts of the Statute for a European Company (SE)", 
origen pueda oponerse a la operación alegando «razones de interés público»" lo cual podría introducir un factor de riesgo para las sociedades europeas interesadas en realizar estas operaciones debido al coste potencial que la paralización del traslado de domicilio social podría suponer o la exigencia de que la sede de administración central de la sociedad europea deba trasladarse con el domicilio social ${ }^{74}$.

Del mismo modo, podría decirse que la aprobación de la Directiva $2005 / 56 / \mathrm{CE}^{75}$ ha aportado una nueva vía para articular estas operaciones a través de la creación ex novo de una filial de la sociedad en el pretendido Estado miembro de destino que posteriormente absorbería a su matriz situada en el Estado de origen, lo que evitaría que la sociedad en cuestión tuviese que liquidarse en su Estado miembro de origen y reconstituirse en el Estado miembro de destino con todas las implicaciones que esto conlleva ${ }^{76}$. En este sentido, es importante tener presente que la Directiva 2005/56/CE no establece criterios de conexión para determinar la lex societatis aplicable a las sociedades participantes en la operación, sino que su art. 4.1, apartado b) se limita a disponer que «una sociedad que participe en una fusión transfronteriza deberá cumplir con las disposiciones y trámites de la legislación nacional a la

julio 2010, pp. 7-8 y 12-16, disponible en: http://ec.europa.eu/internal_market/consultations/docs/2010/se/summary_report_en.pdf (consultado por última vez el 10-12017), o en COMISIÓN EUROPEA, «Accompanying document to the Report from the Commission to the European Parliament and the Council on the application of Council Regulation 2157/2001 of 8 October 2010 on the Statute for a European Company (SE)», SEC (2010) 1391 final, 17-11-2010, pp. 7-13.

73 Véase art. 8.14 del Reglamento (CE) 2157/2001.

74 Véase art. 7 del Reglamento (CE) 2157/2001.

75 Directiva 2005/56/CE del Parlamento Europeo y del Consejo, de 26 de octubre de 2005 relativa a las fusiones transfronterizas de las sociedades de capital (DOUE L 310 , de 25 de noviembre de 2005, p. 1).

76 A este respecto, nótese que, con anterioridad a la entrada en vigor de la citada directiva, la viabilidad de este procedimiento quedaba condicionada a que las legislaciones de los Estados miembros involucrados en la operación de fusión transfronteriza permitiesen su realización, así como a toda la problemática derivada de la interacción entre los ordenamientos domésticos a los que estaban sujetas la sociedad absorbida (Estado miembro de origen) y la sociedad absorbente (Estado miembro de destino); todo ello, sin mencionar el coste fiscal que tendría la operación de realizarse con anterioridad a la entrada en vigor de la Directiva 90/434/CEE del Consejo, de 23 de julio de 1990, relativa al régimen fiscal común aplicable a las fusiones, escisiones, aportaciones de activos y canjes de acciones realizados entre sociedades de diferentes Estados miembros (DOCE L 225, de 20 de agosto de 1990, p. 1). 
que esté sujeta». Por ello, si el Estado miembro de destino aplica el modelo de la sede real, la realización con éxito de la operación requerirá que la sede efectiva de la sociedad absorbente (fusión por absorción) o de la nueva sociedad resultante de la operación (fusión por constitución) quede situada en dicho Estado miembro junto con la sede social.

Ahora bien, aun cuando el uso de estas vías «indirectas» amparadas por el Reglamento (CE) 2157/2001 y por la Directiva 2005/56/CE para llevar a cabo el traslado transfronterizo del domicilio social contribuye a eliminar los problemas que presenta la operación en relación con la protección de accionistas, acreedores o trabajadores, y puede suponer una reducción de costes en comparación con la realización de la misma de forma "directa»" ${ }^{77}$, esto es, a través de la aplicación de las legislaciones societarias de los Estados miembros involucrados en la operación cuando estas no permiten que la operación se lleve a cabo con mantenimiento de la personalidad jurídica, no cabe duda de que la regulación del traslado transfronterizo del domicilio social a través de normas de naturaleza europea y, muy especialmente, el diseño de un procedimiento específico para su ejecución, permitiría garantizar los objetivos anteriormente mencionados a un coste incluso menor $^{78}$.

77 Nótese cómo, a pesar de que el uso de estas alternativas «indirectas» para llevar a cabo un traslado transfronterizo de la sede social no elimina el coste de creación de una sociedad (filial) en el Estado miembro de destino y añade los costes derivados del propio proceso de fusión, lo cierto es que desde el momento en que no resulta necesaria la liquidación de la sociedad en el Estado miembro de origen desaparecen todos los gastos administrativos, fiscales y financieros derivados de esta operación, produciéndose un ahorro en términos netos. A este respecto, resultará esencial que la operación de fusión a través de la cual pretende articularse el traslado transfronterizo del domicilio social quede cubierta por el régimen de neutralidad fiscal previsto en la Directiva 2009/133/CE.

78 En este sentido, véase COMISIÓN EUROPEA, «Report of the reflection group on the future of EU company law», Bruselas, 5-4-2011, p. 20, disponible en: http://ec.europa.eu/internal_market/company/docs/modern/reflectiongroup_report_ en.pdf (consultado por última vez el 3-1-2017), y COMISIÓN EUROPEA, «Feedback statement. Summary of responses to the public consultation on cross-border transfers of registered offices of companies", septiembre 2013, pp. 9 y 13. En particular, y con respecto al uso de la sociedad europea, se ha destacado que la decimocuarta directiva permitiría ahorrar los elevados costes de formación de una sociedad europea que se sitúan de media en unos 784000 euros (incluidos los costes fiscales, de asesoría jurídica, y de registro, así como los gastos de traducción) en una horquilla que oscila entre los 100000 euros y los cuatro millones de euros (véase COMISIÓN EUROPEA, «Informe de la Comisión al Parlamento Europeo y al Consejo sobre la aplica- 


\section{LA NECESIDAD DE DAR UNA RESPUESTA AL PROBLEMA DEL TRASLADO TRANSFRONTERIZO DEL DOMICILIO SOCIAL DESDE EL PLANO DEL DERECHO POSITIVO EUROPEO}

\section{CONSIDERACIONES GENERALES}

Tal y como hemos apuntado en el epígrafe anterior de este trabajo, la jurisprudencia del TJUE en el ámbito de la libertad de establecimiento ha contribuido de forma decisiva a facilitar el traslado del domicilio social entre Estados miembros a través de operaciones de transformación transfronteriza. Sin embargo, no conviene perder de vista que, en ausencia de una norma europea específica en la materia, serán los derechos nacionales de los Estados miembros de origen y de destino los encargados de establecer las normas aplicables a la operación, sin perjuicio de que estas queden sometidas al control de los arts. 49 y 54 del TFUE ${ }^{79}$. De este modo, y desde la óptica del principio de seguridad jurídica, parece que, aun cuando los Estados miembros hayan adoptado normas orientadas a facilitar el traslado transfronterizo de la sede social (p.ej. España, Francia o Italia), el carácter heterogéneo de las mismas

ción del Reglamento (CE) 2157/2001 del Consejo, de 8 de octubre de 2001, por el que se aprueba el Estatuto de la Sociedad Anónima Europea (SE)», COM (2010) 676 final, 17-11-2010, p. 5). Por otra parte, y con respecto al uso de la fusión transfronteriza regulada por la Directiva 2005/56/CE, se ha destacado que la aprobación de la decimocuarta directiva supondría un ahorro de costes, tanto en el supuesto de que la sociedad en cuestión llevase a cabo el traslado de domicilio a través de su absorción por parte de una filial ya existente en el Estado miembro de destino (en cuyo caso se ahorraría solo la diferencia entre los elevados costes del proceso de fusión transfronteriza y los inherentes al proceso de traslado transfronterizo del domicilio social de conformidad con la decimocuarta directiva), como en el supuesto de que la sociedad en cuestión tuviese que crear ad hoc una filial en el Estado miembro de destino por la que posteriormente sería absorbida al objeto de completar el traslado de domicilio (en cuyo caso el ahorro sería mayor, habida cuenta de que a los costes derivados del proceso de fusión transfronteriza habría que sumarle los costes de constitución de la sociedad filial instrumental en el Estado miembro de destino). Sobre esta cuestión, véase Patrice MULLER, Shaan DEVNANI, Rohit LADHER y Paula RAMADA, «European Added Value Assessment on a Directive on the cross-border transfer of company seats (14th Company Law Directive). ANNEX II. Economic and Social Effects of the Requested Legislative Instrument», Research Paper by London Economics Ltd., Brussels, 2013, pp. 54-49.

79 Véase Sentencia del TJUE de 12 de julio de 2012, VALE Építési Kft, C-378/10, EU:C: 2012:440, apartados 43-45. 
seguirá constituyendo un importante hándicap para la realización de dichas operaciones.

En cualquier caso, y a título de ejemplo, no puede perderse de vista cómo en nuestro país, los arts. 92 a 103 de la Ley 3/2009, de 3 de abril, sobre modificaciones estructurales de las sociedades mercantiles (BOE núm. 82, de 4 de abril de 2009) han configurado un régimen jurídico específico aplicable a las operaciones de traslado transfronterizo del domicilio social que no solo busca garantizar la conservación de la personalidad jurídica de la sociedad en el marco de las mismas, sino que facilita y aporta seguridad jurídica a su realización ${ }^{80}$. Asimismo, y por lo que respecta al ámbito registral, estas disposiciones deben ser puestas en relación con los arts. 20, 160 y 161 del RRM para aquellos supuestos de traslado de la sede social al extranjero de una sociedad constituida con arreglo al ordenamiento jurídico español, y con el art. 309 del RRM cuando se trate del traslado a España de la sede social de una sociedad extranjera.

Ciertamente, y aun sin ánimo de profundizar en el régimen español ${ }^{81}$, pues excedería con mucho el objeto de este trabajo, cabría destacar que una de las principales ideas sobre las que se construye pivota sobre el mantenimiento de la personalidad jurídica de las sociedades mercantiles ${ }^{82}$, que trasladan su domicilio de forma tal que, por una parte, no se impone la necesidad de que las sociedades extranjeras que trasladan su domicilio a España tengan que disolverse en su Estado miembro de origen, si bien deberán adaptarse al ordenamiento español y sujetarse al mismo, en concreto a los requisitos establecidos para la constitución de la sociedad cuyo tipo ostenten (salvo que tratados o convenios internacionales vigentes en España dispongan otra cosa) y, por otra, se posibilita el traslado al extranjero de la sede social de una sociedad española

80 A este respecto, podría apuntarse cómo entre los años 2010 y 2012, un total de veintinueve empresas iniciaron (o incluso llegaron a completar) los trámites para trasladar su domicilio social desde España a otros países de conformidad con el procedimiento establecido en los citados preceptos de la LME, eligiendo como destino la Unión Europea un $62 \%$ de las mismas (véase CATHIARD, op. cit., nota 45, pp. 37 y 43).

81 Un completo análisis del mismo puede encontrarse en ESTEBAN DE LA ROSA, $o p$. cit., nota 2, pp. 84-106, o Pedro ÁVILA NAVARRO, Modificaciones estructurales de sociedades mercantiles. Ley 3/2009, tomo I, Bosch, Barcelona, 2009, pp. 603-629.

82 Nótese como el régimen previsto en los arts. 92 a 103 de la LME no resulta de aplicación a las sociedades cooperativas en virtud de lo establecido en el art. 2 de la propia LME. Sobre esta cuestión, véase Javier CARRASCOSA GONZÁLEZ, «Notas sobre el traslado internacional del domicilio social de las cooperativas tras la Ley 3/2009, de 3 de abril, sobre modificaciones estructurales de las sociedades mercantiles», Diario La Ley, núm. 7294, de 30 de noviembre de 2009. 
sin que esto afecte a la continuidad de su personalidad jurídica, siempre que el Estado miembro de destino así lo permita ${ }^{83}$.

Asimismo, no puede dejar de señalarse la falta de diferenciación existente entre el régimen jurídico-procedimental establecido para el traslado de la sede social de una sociedad española hacia un Estado miembro de la UE y el aplicable a esta misma operación cuando el Estado de destino no forma parte de la $\mathrm{UE}^{84}$. Sin embargo, tratándose de la situación inversa (traslado a España del domicilio social de una sociedad extranjera), la LME sí que introduce diferencias en función de si el Estado de origen forma parte o no del Espacio Económico Europeo; así, en el primer supuesto, la ley deja claro que «el traslado al territorio español del domicilio de una sociedad constituida conforme a la ley de otro Estado parte del Espacio Económico Europeo no afectará a la personalidad jurídica de la sociedad $\aleph^{85}$, mientras que en el segundo supuesto se exige que la legislación del Estado de origen permita la operación de traslado con mantenimiento de la personalidad jurídica ${ }^{86}$, lo cual ha suscitado algunas críticas por parte de la doctrina ${ }^{87}$. En relación con esta cuestión, también se echa de menos una aclaración por parte de la LME acerca de si las sociedades en liquidación o en concurso de acreedores pueden trasladar su domicilio social a España ${ }^{88}$, posibilidad que la propia ley veta a las sociedades españolas que pretenden trasladar su sede social al extranjero ${ }^{89}$.

83 En este sentido, véase Miguel GARDENES SANTIAGO, Diana SANCHO VILLA y Carolina UPEGUI VILLEGAS, «La ley 3/2009, de 3 de abril, sobre modificaciones estructurales de las sociedades mercantiles y el Derecho Internacional Privado de sociedades", Anuario de Derecho Internacional Privado, t. IX, 2009, p. 606, que matizan que si el principal establecimiento o explotación de la sociedad permanece en España, la sociedad seguirá siendo española de acuerdo con lo establecido en el actual art. 9.2 de la LSC y la decisión de traslado será considerada nula. A este respecto, nótese que la cuestión acerca de si el Estado de destino permite el mantenimiento de la personalidad jurídica de la sociedad podrá ser probado por las partes, sin perjuicio de que la remisión efectuada por el art. 5.3 del RRM al art. 36 del Decreto de 14 de febrero de 1947 por el que se aprueba el Reglamento Hipotecario (BOE núm. 106, de 16 de abril de 1947), faculta al registrador mercantil español para realizar las indagaciones oportunas para averiguar tal extremo.

84 Véase art. 93.1 de la LME.

85 Véase art. 94.1 de la LME.

86 Véase art. 94.2 de la LME.

87 En este sentido, véase ESTEBAN DE LA ROSA, op. cit., nota 2, p. 86.

88 En este sentido, véase ÁVILA NAVARRO, op. cit., nota 81, p. 624.

89 Véase art. 93.2 de la LME. A este respecto, DOMÍNGUEZ PUNTAS, op. cit., nota 22 , p. 72, matiza que el traslado del domicilio social al extranjero por parte de una so- 
Por otra parte, y por lo que respecta a la exigencia de un informe elaborado por un experto independiente que acredite que el patrimonio neto de las sociedades extranjeras de capital que pretendan trasladar su domicilio social a España desde un Estado no miembro del EEE cubre la cifra del capital social exigido por el derecho español ${ }^{90}$, algunos autores han apuntado que este requisito podría resultar excesivo en el ámbito de las sociedades anónimas si se pone en relación con lo establecido en el art. 79 de la LSC (que tan solo exige que esté desembolsada una cuarta parte del valor nominal de las acciones de la sociedad en el momento de otorgar escritura de constitución), más aun cuando la aplicación del citado precepto ya tendría entrada en virtud del propio tenor literal del art. 94.1 de la $\mathrm{LME}^{91}$.

Asimismo, algunos autores también han llamado la atención acerca de que, en ausencia de una disposición expresa en la LME, no resulta claro, por una parte, si puede admitirse por analogía la posibilidad de que el acuerdo de traslado transfronterizo del domicilio social se acuerde en junta universal sobre la base de un proyecto previo presentado por los administradores o improvisado en el mismo acto y, por otra parte, si el acuerdo de traslado debe ser sometido a publicidad una vez adoptado, tal y como sucede en otras operaciones de reorganización empresarial (p.ej. las fusiones), lo cual resulta de capital importancia para el cómputo del plazo del que disponen los socios y los acreedores para ejercitar, respectivamente, sus derechos de separación y oposición ${ }^{92}$.

Por lo que respecta al reconocimiento de un derecho de separación en favor de los socios que hubieran votado en contra del acuerdo de traslado ${ }^{93}$, han surgido voces que alertan acerca de los problemas que surgirían si como resultado de la consiguiente reducción de capital, la cifra de capital social descendiera por debajo del mínimo legal exigido en España, caso en el que se procedería a la disolución de la sociedad en el plazo de un año desde la adop-

ciedad española en este tipo de supuestos sería posible de haberse «firmado y aprobado judicialmente un convenio con los acreedores en el que se permita dicho traslado».

90 Véase art. 94.1, párrafo segundo de la LME.

91 En este sentido, véase ESTEBAN DE LA ROSA, op. cit., nota 2, pp. 87-88. No obstante, y a favor de la exigencia de este requisito, incluso cuando la sociedad en cuestión procede de un Estado miembro de la UE, véase DOMÍNGUEZ PUNTAS, op. cit., nota 22, pp. 79-80.

92 Sobre estas cuestiones véase ÁVILA NAVARRO, op. cit., nota 81, pp. 613-615, quien, en relación con la segunda de las cuestiones planteadas, se muestra partidario de la necesidad de que se publique el acuerdo de traslado en línea con lo que sucede en el ámbito de las fusiones.

93 Véase art. 99 de la LME. 
ción del acuerdo de reducción de capital ${ }^{94}$, salvo que el traslado ya se hubiese completado y se superase al capital mínimo exigido por la legislación societaria del Estado de destino. Por ello, y desde la óptica del principio de seguridad jurídica, se ha apuntado que «lo más apropiado sería que el acuerdo de traslado hubiera quedado condicionado a la no separación de un concreto número de socios, pues de lo contrario el camino a seguir habrá de ser la revocación del acuerdo, la cual se puede producir hasta el momento de la inscripción del cambio de sede en el registro extranjero" ${ }^{95}$.

En último lugar, y en materia de derecho registral, el contenido del art. 309 del RRM relativo a la publicidad registral de las operaciones de traslado del domicilio social a España por parte de sociedades extranjeras tampoco ha estado exento de críticas por parte de la doctrina entre las que cabría señalar: a) la incertidumbre acerca del momento en el que la sociedad en cuestión comienza a regirse por el derecho español; b) la ausencia de algún tipo de mecanismo de control que facilite al registrador la verificación de que el acuerdo de traslado de ha adoptado en conformidad con lo establecido por el derecho extranjero ${ }^{96}$, o c) la ausencia de instrumentos que contribuyan a coordinar la actuación de los registradores nacionales y extranjeros, evitando la posible existencia de sociedades doblemente inscritas o no inscritas en el Registro de ningún Estado ${ }^{97}$.

En cualquier caso, y más allá de las bondades y carencias propias del régimen configurado por la LME, lo cierto es que ya desde comienzos de la década de los ochenta comenzó a ponerse en evidencia que, a falta de un acuerdo entre los Estados miembros para dar cumplimiento a sus obligaciones conforme al antiguo art. 220 del TCEE, los arts. 49 y 54 del TFUE no resul-

Véase art. 360 de la LSC.

95 En este sentido, véase ESTEBAN DE LA ROSA, op. cit., nota 2, p. 100.

96 A este respecto, algunos autores como ESTEBAN DE LA ROSA, op. cit., nota 2, pp. 89-90, se han mostrado partidarios de que, en lugar de que el registrador español lleve a cabo una calificación «amplia» de la legalidad de la operación de traslado (lo cual plantea el problema de la prueba del derecho extranjero y las consecuencias de su falta de acreditación), se establezca una distribución del control de legalidad entre las autoridades nacionales competentes de los Estados miembros involucrados en la operación.

97 Sobre esta cuestión, véase BLANCO-MORALES LIMONES, op. cit., nota 6, pp. 121-124; SANCHO VILLA, op. cit., nota 5, pp. 277-278, o GARDENES SANTIAGO, SANCHO VILLA y UPEGUI VILLEGAS, op. cit., nota 83, p. 596. Más en profundidad, acerca de la inmigración de sociedades extranjeras a territorio español sobre la base del art. 309 del RRM, véase ARENAS GARCIA, op. cit., nota 14, pp. 247-251. 
taban suficientes para dar respuesta a las necesidades de movilidad transfronteriza de las empresas europeas, garantizando el derecho de establecimiento de las personas jurídicas en el marco de operaciones de traslado transfronterizo del domicilio social. Sin embargo, los primeros intentos de adoptar una norma europea tendente a facilitar el traslado transfronterizo de la sede social o real de las sociedades de los diferentes Estados miembros datan de 1993, con la publicación de los resultados de un estudio encargado por la Comisión y llevado a cabo por el KPMG European Business Centre ${ }^{98}$. Las conclusiones de dicho estudio cristalizarían en 1997 en la elaboración de un borrador de Propuesta de decimocuarta directiva relativa al traslado de la sede de las sociedades de un Estado miembro a otro con cambio de la legislación vigente (que nunca llegaría a ser presentado oficialmente como tal ${ }^{99}$ ), cuya idea central residía en que el traslado transfronterizo de la sede social o real de una sociedad no debía dar lugar ni a una disolución ni a la creación de una nueva persona jurídica ${ }^{100}$.

98 Véase COMISIÓN EUROPEA, «Study on the transfer of the head office of a company from one member state to another", Bruselas, 1993, disponible en: http://bookshop. europa.eu/en/study-on-transfer-of-the-head-office-of-a-company-from-one-memberstate-to-another-pbC17993017/ (consultado por última vez el 4-1-2017). A este respecto, nótese como si bien el núcleo de este estudio se centraba en analizar qué medidas serían adecuadas para facilitar el traslado de la sede real de la sociedad de un Estado miembro a otro sin que se produjese su disolución y liquidación, también contenía algunas propuestas en el ámbito del traslado la sede social con mantenimiento de la personalidad jurídica, a saber: por una parte, se hacía referencia a la posibilidad (muy ambiciosa) de llevar a cabo la operación sin que se produjese un cambio de la ley aplicable a través del mero reconocimiento e inscripción registral por parte del Estado miembro de destino de la sociedad en cuestión; y, por otra, se hacía referencia a la posibilidad de que la operación conllevase un cambio de la ley aplicable a la sociedad en cuestión, quedando esta sometida a la legislación del Estado miembro de destino (sobre esta cuestión, véase RODAS PAREDES, op. cit., nota 8, p. 63).

99 Una primera versión de este borrador elaborado por la Comisión Europea llevaba fecha del 22 de mayo de 1997 (Documento núm. XV/D2/6002/97), siendo posteriormente revisado el 11 de junio de 1997 (Documento núm. XV/D2/6002/97-EN REV.2). Sobre esta cuestión, véase Christiana HJI PANAJI, "Corporate Mobility in Private International Law and European Community Law: Debunking some Myths", Yearbook of European Law 2009, Clarendon Press, Oxford, 2010, p. 140.

100 Véase art. 3 del Borrador de Propuesta de decimocuarta directiva de 1997. A este respecto, se ha afirmado que «la Directiva no pretende unificar las reglas conflictuales: deja que cada Estado decida qué criterio de conexión (sede real o constitución) va a determinar la lex societatis y, por consiguiente, bajo qué condiciones (traslado de la sede real o del domicilio estatutario) se va a producir un cambio de lex societatis. Esto, 
Con la llegada del nuevo milenio, se intensificaron las reivindicaciones relativas a la necesidad de un mayor grado de aproximación de las legislaciones domésticas de los Estados miembros en el plano del derecho societario, ligadas a la concepción de un auténtico mercado interior en el que, sobre la base de la libertad de establecimiento contemplada en los arts. 49 y 54 del TFUE, las empresas europeas debían operar a nivel transfronterizo en condiciones se seguridad jurídica similares a las que lo hacían en el ámbito interno. En este contexto, y partiendo de la recomendación del Grupo de Expertos de Alto Nivel en Derecho de Sociedades ${ }^{101}$, la Comisión Europea anunciaba en el año 2003 su intención de presentar en el corto plazo (antes de que finalizase el año 2005) una propuesta de directiva relativa al traslado transfronterizo del domicilio social ${ }^{102}$, llegando a elaborar y someter a consulta pública las líneas maestras sobre las que debería pivotar la futura directiva. No obstante, el cumplimiento del plazo previsto sin resultado alguno obligó a la Comisión a reiterar nuevamente en el año 2005 su compromiso con la que sería la decimocuarta directiva en el ámbito del derecho societario europeo ${ }^{103}$.

Finalmente en el año 2007, y tras la realización de numerosas consultas $^{104}$, estudios e intensos debates, la Comisión Europea pareció descartar finalmente la idea de elaborar una propuesta legislativa destinada a aproximar las legislaciones domésticas de los Estados miembros con el fin de posibilitar y facilitar el traslado transfronterizo del domicilio social de las sociedades nacio-

en definitiva, nos lo sigue diciendo el Derecho internacional privado de cada Estado» (véase GARCIMARTÍN ALFÉREZ, op. cit., nota 5, pp. 112-113).

101 Véase COMISIÓN EUROPEA, «Report of the High Level Group of Company Law Experts on a Modern Regulatory Framework for Company Law in Europe», Bruselas, 4-11-2002, p. 20, disponible en: http://ec.europa.eu/internal_market/company/ docs/modern/report_en.pdf (consultado por última vez el 28-1-2017).

102 Véase COMISIÓN EUROPEA, "Comunicación de la Comisión al Consejo y al Parlamento. Modernización del Derecho de sociedades y mejora de la gobernanza empresarial en la Unión Europea: Un plan para avanzar», COM (2003) 284 final, 21-5-2003, pp. 10, 23 y 28.

103 Véase COMISIÓN EUROPEA, «Annex to the Communication from the Commission to the Council and the European Parliament. Common Actions for Growth and Employment: The Community Lisbon Program», SEC (2005) 981, 20-7-2005, p. 6.

${ }^{104}$ A título de ejemplo, véase COMISIÓN EUROPEA, «Consultation and hearing on future priorities for the action plan on modernising company law and enhancing corporate governance in the European Union. Summary report», Bruselas, 2006, p. 3, disponible en: http://ec.europa.eu/internal_market/company/docs/consultation/ consultation_en.pdf (consultado por última vez el 24-1-2017). 
nales de dichos Estados ${ }^{105}$, si bien el Parlamento Europeo se reservó el derecho seguir estudiando la cuestión para emprender en el futuro nuevas actuaciones en la materia ${ }^{106}$. A este respecto, cabría apuntar cómo la resolución dada por el TJUE al asunto Cartesio no vino sino a confirmar el posicionamiento del Parlamento Europeo, cuyo trabajo de reflexión y análisis se ha mantenido hasta la actualidad, traduciéndose en diversas peticiones formales a la Comisión para que presente, a la mayor brevedad posible, una Propuesta de decimocuarta directiva en materia de derecho societario europeo, acompañadas de una serie de recomendaciones acerca de su contenido ${ }^{107}$. De hecho, en una consulta

${ }^{105}$ A modo de síntesis, podría decirse que, en el ámbito de las operaciones de traslado transfronterizo del domicilio social, y al objeto de mejorar la eficiencia y la competitividad de las empresas europeas a nivel internacional así como de garantizar los derechos de los colectivos afectados por la operación, la Comisión Europea se planteaba varias líneas de actuación, a saber: a) no adoptar ninguna medida, dejando la cuestión en manos de los Estados miembros; b) emplear instrumentos jurídicos europeos flexibles y no vinculantes — p. ej. recomendación-; c) proponer una directiva, o d) proponer un reglamento. Finalmente, y después de un detallado análisis de los efectos, costes, ventajas e inconvenientes de las diferentes opciones, la Comisión determinó que los objetivos anteriormente descritos podrían alcanzarse a través de la «no acción» o mediante la adopción de una directiva en la materia. No obstante, tras aplicar un test de proporcionalidad, se llegó a la conclusión final de que esta última posibilidad no constituía la forma menos onerosa de lograr los fines perseguidos habida cuenta de que, por una parte, todavía no se conocía el efecto que tendría la Directiva 2005/56/ $\mathrm{CE}$ en la movilidad transfronteriza de las sociedades europeas y, por otra parte, se esperaba que la cuestión del traslado transfronterizo del domicilio social quedase aclarada por el TJUE que, en ese momento, tenía pendiente de resolución el asunto Cartesio (sobre esta cuestión, véase COMISIÓN EUROPEA, «Impact assessment on the Directive on the cross-border transfer of registered office», $\operatorname{SEC}(2007) 1707,12$ 12-2007, pp. 29-52).

106 En este sentido, véase Resolución del Parlamento Europeo, de 25 de octubre de 2007, sobre la Sociedad Privada Europea y la decimocuarta directiva sobre el derecho de sociedades sobre la transferencia de la sede social de una sociedad, P6_TA(2007)0491, aps. 5 y 6 (DOUE C 263 E, de 16 de octubre de 2008, p. 671).

107 Véase, a título de ejemplo, la Resolución del Parlamento Europeo, de 14 de junio de 2012, sobre el futuro del derecho europeo de sociedades, P7_TA(2012)0259, apartados 7-8 (DOUE C 332 E, de 15 de noviembre de 2013, p. 78; o la Resolución del Parlamento Europeo de 2 de febrero de 2012, con recomendaciones destinadas a la Comisión sobre la decimocuarta directiva sobre derecho de sociedades referente al traslado transfronterizo del domicilio social de las empresas, P7_TA(2012)0019 (DOUE C 239 E, de 20 de agosto de 2013, p. 18). A este respecto, es importante destacar que las peticiones del Parlamento Europeo encontraban el respaldo de un 
pública lanzada por la Comisión Europea en el año 2012, el 68 \% de los participantes se mostró a favor de la aprobación de una directiva que contribuya a eliminar los obstáculos tradicionalmente asociados al traslado transfronterizo de la sede social ${ }^{108}$.

Otra alternativa que también se ha contemplado consistiría en dar cobertura al traslado transfronterizo del domicilio social a través de la modificación (y ampliación del ámbito de aplicación objetivo) de la Directiva 2005/56/CE en materia de fusiones transfronterizas. Esta opción presenta a priori la ventaja de que podrían extenderse, con las debidas adaptaciones, las normas sobre protección de accionistas minoritarios, trabajadores y acreedores contenidas en la misma, evitando duplicidades innecesarias y garantizando la coherencia de la protección de los intereses de estos colectivos en el ámbito de la movilidad transfronteriza empresarial ${ }^{109}$. No obstante, en nuestra opinión, y a diferencia de lo que sucede entre las operaciones de fusión y escisión, que pueden ser vistas como las dos caras de una misma moneda, el traslado transfronterizo del domicilio social presenta una naturaleza e implicaciones jurídicas diferen-

importante sector de la doctrina, especialmente tras la resolución dada por el TJUE al asunto Cartesio (véase, entre otros, Mathias KRARUP, «VALE: Determining the Need for Amended Regulation Regarding Free Movement of Companies within The EU», European Business Law Review, vol. 24, núm. 5, 2013, p. 698, o Gert-Jan VOSSESTEIN, "Cross-Border Transfer of Seat and Conversion of Companies under the EC Treaty Provisions on Freedom of Establishment. Some Considerations on the Court of Justice's Cartesio Judgment», European Company Law, vol. 6, núm. 3, 2009, p. 123), pero también con anterioridad a la misma (véase Eddy WYMEERSCH, «Is a Directive on Corporate Mobility Needed?», European Business Organization Law Review, vol. 8, 2007, p. 169, y MUCCIARELLI, op. cit., nota 24, pp. 302-303).

108 Véase COMISIÓN EUROPEA, «Feedback statement. Summary of responses to the public consultation on the future of European company law», Bruselas, julio 2012, p. 9, disponible en: http://ec.europa.eu/internal_market/consultations/docs/2012/companylaw/feedback_statement_en.pdf (consultado por última vez el 12-2-2017). A este respecto cabría apuntar que no se trata de un dato aislado, sino que viene a reafirmar los resultados obtenidos en consultas anteriores llevadas a cabo por la Comisión, mostrando la existencia de un sentir mayoritario en diversos colectivos dentro de la Unión Europea (empresas, sindicatos, abogados, notarios, federaciones empresariales, etc.).

109 A este respecto, se ha apuntado incluso la posibilidad de crear una suerte de «macro directiva» que recogiese en un mismo cuerpo normativo el régimen jurídico-procedimental aplicable a fusiones, escisiones y traslados de domicilio en el ámbito transfronterizo y que sirviese de punto de referencia para las empresas europeas en el ámbito de la movilidad transfronteriza (véase COMISIÓN EUROPEA, "Report of the reflection group on the future of EU company law», Bruselas, 5-4-2011, pp. 21-22). 
ciadas que aconsejan la elaboración de una norma específica de derecho de la UE que aporte una mayor claridad a los operadores económicos acerca del régimen jurídico-procedimental aplicable a estas operaciones sin perjuicio, claro está, de que éste deba estar inspirado en las disposiciones de la Directiva 2005/56/CE.

En cualquier caso, lo cierto es que tanto la adopción de una directiva en materia de traslado transfronterizo del domicilio social como la incorporación de normas específicas para estas operaciones en el ámbito de la actual Directiva 2005/56/CE, contribuiría no solo al desarrollo de la libertad de establecimiento prevista en los arts. 49 y 54 del TFUE, sino también a facilitar la movilidad transfronteriza de las empresas de los diferentes Estados miembros, permitiendo la elección del contexto legislativo que mejor se adapte a sus necesidades e incrementando su competitividad a nivel internacional, así como a la realización y buen funcionamiento del mercado interior.

\section{ALGUNAS CUESTIONES CLAVE ACERCA DE LA FUTURA DECIMOCUARTA DIRECTIVA EN MATERIA DE DERECHO SOCIETARIO EUROPEO}

Una vez que, sobre la base de lo expuesto en los anteriores epígrafes de este trabajo, ha quedado de manifiesto la necesidad de dar una respuesta desde la óptica del derecho positivo europeo a la problemática que sigue planteando en la actualidad el traslado transfronterizo de la sede social, cabría referirnos sucintamente a algunas cuestiones clave para que la futura directiva sobre el traslado transfronterizo del domicilio social pueda alcanzar con éxito los fines perseguidos ${ }^{110}$. Así, en primer lugar, estaría la conveniencia de que el ámbito de aplicación subjetivo de la pretendida directiva sobre el traslado transfronterizo del domicilio social pivote sobre el concepto de «sociedades de capital»,

${ }^{110}$ En este sentido, partiremos de la base de algunas de las recomendaciones que, a lo largo de estos últimos años, ha venido realizando el Parlamento Europeo en esta materia, las cuales pueden encontrarse en la Resolución del Parlamento Europeo de 2 de febrero de 2012, con recomendaciones destinadas a la Comisión sobre la decimocuarta directiva sobre derecho de sociedades referente al traslado transfronterizo del domicilio social de las empresas, P7_TA(2012)0019 (DOUE C 239 E, de 20 de agosto de 2013, p. 18) o en la Resolución del Parlamento Europeo, de 10 de marzo de 2009, con recomendaciones destinadas a la Comisión sobre el traslado transfronterizo de la sede social de una empresa, PA_TA(2009)0086 (DOUE C 87 E, de 1 de abril de 2010, p. 5). 
tal y como se definen en el art. 2.1 de la Directiva 2005/56/CE ${ }^{111}$. A nuestro juicio, esta decisión dotaría a la directiva de un importante grado de flexibilidad, posibilitando el acceso de las pymes a los beneficios contemplados en la misma de forma similar a lo que sucede en el ámbito de las fusiones transfronterizas. Ciertamente, no debemos olvidar que el uso de la sociedad europea y del Reglamento (CE) 2157/2001 como vía alternativa para llevar a cabo el traslado de domicilio social tan solo resulta efectivo para las sociedades anónimas (dejando fuera a la mayoría de pymes), de ahí la importancia de que la futura decimocuarta directiva amplíe el catálogo de tipos societarios cubiertos por su ámbito de aplicación subjetivo.

En segundo lugar, tendríamos la necesidad de que la decimocuarta directiva aporte una "solución apropiada» a la cuestión de la separación de la sede social y la sede efectiva de la sociedad ${ }^{112}$; aspecto sobre el que la Propuesta de Directiva de 1997 no resultaba ni mucho menos clarificadora ${ }^{113}$. Ciertamente, y aun reconociendo la existencia de importantes argumentos a favor de la obligatoriedad de que el traslado de la sede social venga acompañado del traslado de la sede de dirección efectiva al mismo Estado miembro (p.ej.

111 En este sentido, no puede perderse de vista que la Propuesta de Directiva de 1997, en su art. 1, se refería únicamente al término «sociedades» lo que introducía un componente de incertidumbre acerca de cuáles eran concretamente las formas societarias cubiertas por su ámbito de aplicación subjetivo y sobre su extensión a otras entidades jurídicas que no podían ser consideradas como sociedades de capital.

112 De hecho, una consulta pública lanzada por la Comisión Europea en el año 2013 puso de manifiesto la dificultad de dar una respuesta a este problema habida cuenta de lo equilibrado entre las posiciones divergentes sostenidas, de un lado, por las autoridades nacionales, los sindicatos y una parte minoritaria de las empresas, que entendían que el traslado del domicilio social debería venir acompañado necesariamente del traslado de la sede de dirección efectiva y, de otro, por la mayoría de las empresas participantes, que se inclinaban por la tesis contraria (véase COMISIÓN EUROPEA, «Feedback statement. Summary of responses to the public consultation on cross-border transfers of registered offices of companies», septiembre 2013, pp. 13-14).

113 De hecho, el art. 1 de la citada propuesta establecía que la futura directiva se aplicaría a las «operaciones de traslado de un Estado miembro a otro de la sede social o real de las sociedades constituidas de conformidad con la legislación de un Estado miembro y cuya sede social y administración central estén situadas dentro de la Comunidad»; $a$ priori esto podría dar a entender que la sede social y la sede real pueden trasladarse de forma independiente, si bien a reglón seguido el art. 2 de la citada propuesta de directiva define la sede real como el «lugar en el que tenga su administración central y esté registrada una sociedad» (la cursiva es nuestra), lo cual parece establecer una identidad entre el lugar en donde esté situada la sede social y la sede real de la sociedad. 
la necesidad de evitar las prácticas abusivas de forum shopping, la garantía de la seguridad jurídica de la operación o la protección de los derechos de los accionistas minoritarios, trabajadores y terceros), entendemos, por una parte, que esta opción tendría un impacto negativo en la utilidad y vigencia efectiva de la directiva en la medida en que reduciría la capacidad de adaptación de las empresas a los cambios del mercado, cerrando la posibilidad de escoger con posterioridad a su creación el entorno legislativo que mejor se adapte a sus necesidades y, por otra parte, que en el marco de la regulación del procedimiento de traslado de domicilio social previsto por la directiva podrían adoptarse otras medidas menos restrictivas tendentes a garantizar los intereses anteriormente mencionados ${ }^{114}$. A nuestro juicio, no sería necesario que el traslado de la sede social venga acompañado del traslado de la sede real, siempre que pueda acreditarse la implantación real y el ejercicio efectivo de una actividad económica en el Estado miembro de destino por parte de la sociedad en cuestión, de forma tal que no puedan beneficiarse del régimen de la directiva «montajes puramente artificiales» que simplemente pretendan eludir la legislación (más estricta) del Estado miembro de origen ${ }^{115}$.

${ }^{114}$ En favor de esta opción se ha mostrado la Cámara de Comercio e Industria de París, afirmando que, de este modo, se "consagraría definitivamente la teoría de la incorporación» frente a la teoría de la sede real, línea en la que poco a poco parece avanzar la jurisprudencia del TJUE (véase Dominique DAMON, Consultation sur l'avenir du droit européen des sociétés. Réactions de la CCIP, Chambre de commerce et d'industrie de Paris, 2012, p. 17, disponible en : http://www.etudes.cci-paris-idf.fr/rapport/323 (consultado por última vez en 5-1-2017).

115 De hecho, algunos estudios muestran cómo los riesgos potenciales para los diferentes stakeholders de la sociedad son mayores cuando se produce el traslado simultáneo de la sede social y la sede real en la medida en que resultará más probable que se produzcan cambios en la normativa aplicable a diferentes ámbitos (derecho concursal, derecho tributario, derecho contractual, derecho societario, etc.). Sobre esta última cuestión, véase CATHIARD, op. cit., nota 45, pp. 72-75. En este sentido, resulta interesante la propuesta realizada en el citado estudio (p. 91) que, al objeto de conciliar un grado aceptable de flexibilidad para las empresas con la necesidad de evitar posibles abusos en el marco de estas operaciones, apuesta porque la futura decimocuarta directiva supedite la posibilidad de llevar a cabo el traslado transfronterizo del domicilio social al cumplimiento alternativo de una de las siguientes condiciones: a) el ejercicio efectivo de una actividad económica a través de un establecimiento permanente en el Estado miembro de destino durante un periodo indefinido con posterioridad a la operación; b) la tenencia de un establecimiento en el Estado miembro de destino con anterioridad a la operación, o c) el traslado simultáneo de la sede real y de la sede social. 
En este sentido, no debemos perder de vista que uno de los hándicaps tradicionalmente asociados a la sociedad europea desde la óptica de su contribución a la movilidad transfronteriza de las empresas de los diferentes Estados miembros, y que incluso planteaba dudas desde la óptica de la libertad de establecimiento $^{116}$, residía precisamente en la exigencia impuesta por el art. 7 del Reglamento (CE) 2157/2001 de que el domicilio social y la administración central de la sociedad europea se encontrase situado en el mismo Estado miembro, de forma tal que el traslado del primero llevaba aparejado el traslado del segundo. De hecho, algunos autores han destacado que la adopción de un enfoque flexible a este respecto por parte de la futura decimocuarta directiva, en el sentido de no exigir el traslado simultáneo de la sede social y la sede real, supondría una oportunidad para nivelar o, de algún modo controlar, la competencia legislativa que actualmente existe entre los Estados miembros por lo que refiere a las condiciones en las que se llevan a cabo estas operaciones y a su capacidad para atraer las sedes sociales de sociedades constituidas originariamente en el extranjero (level playing field $v$. non-level playing field $)^{117}$.

Asimismo, resulta conveniente señalar cómo las más actuales tendencias en el ámbito del Derecho societario europeo parecen apostar por la independencia entre la localización del domicilio social y la sede de administración central, tal y cómo se refleja en el art. 10 de la Propuesta de Directiva del Parlamento Europeo y del Consejo, relativa a las sociedades unipersonales privadas de responsabilidad limitada, COM (2014) 212 final, de 9 de abril de $2014^{118}$. Ciertamente, en nuestra opinión, esta debería ser la línea a seguir por el legislador europeo, no solo en el ámbito de la futura directiva sobre el

116 En este sentido, véase Luis FERNÁNDEZ DEL POZO, «Domicilio y nacionalidad de la SE: traslado internacional del domicilio de la SE. La publicidad registral de la SE», en AA. VV., La sociedad anónima europea: régimen jurídico societario, laboral y fiscal, Marcial Pons, Madrid, 2004, p. 172, o WYMEERSCH, op. cit., nota 12, p. 33. De hecho, algunos autores como Wolf-Georg RINGE, «The European Company Statute in the Context of Freedom of Establishment", Journal of Corporate Law Studies, vol. 7, núm. 2, 2007, pp. 200-201, ya se mostraron a favor de que el domicilio social y la sede de la administración central de la sociedad europea puedan localizarse en Estados miembros diferentes.

117 Sobre esta cuestión, véase FRADA DE SOUSA, op. cit., nota 83, p. 64.

118 En este sentido, también la malograda Propuesta de Reglamento del Consejo por el que se aprueba el Estatuto de la Sociedad Privada Europea, COM (2008) 396 final, 25-6-2008, contemplaba la posibilidad de trasladar el domicilio social de esta figura societaria a otro Estado miembro sin que, por una parte, esto diese lugar a la liquidación de la misma o a la interrupción/pérdida de su personalidad jurídica, y por otra parte, fuese necesario trasladar al mismo Estado miembro su administración 
traslado transfronterizo del domicilio social sino también en el del Reglamento (CE) 2157/2001, que debería ser modificado en consecuencia para evitar el surgimiento de una desventaja competitiva para la sociedad europea en relación con las formas societarias nacionales. En cualquier caso, lo cierto es que la decisión acerca de si el traslado de la sede social debe conllevar necesariamente el traslado de la sede de administración central no debería quedar en manos de los Estados miembros, habida cuenta de los potenciales problemas derivados de la falta de homogeneidad en las soluciones adoptadas y la competencia entre sus respectivas legislaciones nacionales en materia societaria ${ }^{119}$.

En tercer lugar, estaría el establecimiento del principio fundamental de que el traslado transfronterizo de la sede social no debe implicar la disolución y la liquidación de la sociedad en el Estado miembro de origen, sino que la operación deberá articularse a través de la conversión en una sociedad sujeta al ordenamiento del Estado miembro de destino. Ciertamente, la idea del mantenimiento de la personalidad jurídica, que ya estaba presente en el art. 3 de la Propuesta de Directiva de 1997, y que se observa no solo en la jurisprudencia del TJUE en los asuntos Cartesio y VALE Épitési sino también en las legislaciones societarias domésticas de algunos Estados miembros, debe constituir el eje de la futura decimocuarta directiva, habida cuenta de que uno de los principales obstáculos que históricamente han imposibilitado el desarrollo de estas operaciones residía precisamente en los elevados costes asociados al proceso de disolución y liquidación de la sociedad en su Estado miembro de origen, y su posterior «reconstitución» en el Estado miembro de destino.

En cuarto lugar, tendríamos la necesidad de que en el marco del traslado transfronterizo del domicilio social se garanticen de forma adecuada los derechos e intereses de aquellos colectivos afectados por la operación tales

central o su centro de actividad principal (véase arts. 7 y 35 de la citada propuesta de reglamento).

119 A este respecto, nótese cómo esta era la opción por la que optaba el Borrador de Propuesta de decimocuarta directiva de 1997, cuyo art. 11.2 reconocía la facultad del Estado miembro de destino para denegar la inscripción de una sociedad que había trasladado su sede social a su territorio si la administración central de la misma no estaba situada dentro del mismo. Por tanto, y cómo bien apunta Lone HANSEN, «Merger, Moving and Division Across National Borders. When Case Law Breaks through Barriers and Overtakes Directives", European Business Law Review, vol.18, núm. 1, 2007, p. 201, esto se traduciría en que la posibilidad de trasladar únicamente el domicilio social quedaría limitada a aquellos supuestos en los que tanto el Estado miembro de origen como el Estado miembro de destino opten por el modelo de la incorporación. 
como los accionistas minoritarios, los trabajadores o los acreedores ${ }^{120}$. A este respecto, resultaría esencial que la decimocuarta directiva contemplase una serie de normas relativas a cuestiones tales como: a) la elaboración por parte de los órganos de dirección o administración de la sociedad de un plan de traslado junto con un informe donde se justifiquen los aspectos económicos, legales y sociales del traslado así como las consecuencias para los accionistas, los acreedores y los trabajadores; b) el derecho de estos colectivos a examinar dicho informe con anterioridad a la celebración de la junta general en la que se decida sobre la operación; c) la preservación de los derechos de participación de los trabajadores en el marco de estas operaciones; d) el contenido mínimo del plan de traslado y su sometimiento a los requisitos de publicidad de acuerdo con la Directiva 2009/101/CE; e) la aprobación por parte de la junta general del plan de $\operatorname{traslado}^{121}$; f) la verificación de la

${ }^{120}$ A este respecto, se ha apuntado que el mero traslado de la sede social de un Estado miembro a otro (sin que se produzca, por tanto, de forma simultánea el traslado de la sede real o de la actividad económica de la sociedad) implica, entre otros, los siguientes riesgos potenciales: a) en relación con los accionistas, tendríamos la modificación de sus derechos y obligaciones como resultado de la aplicación de la ley del Estado miembro de destino, o la modificación de las obligaciones de la sociedad relativas de revelación de información bajo el régimen de la Directiva 2003/71/CE, de 4 de noviembre de 2003, sobre el folleto que debe publicarse en caso de oferta pública o admisión a cotización de valores (DOCE L 345, de 31 de diciembre de 2003, p. 64), y de la Directiva 2007/14/CE, de 8 de marzo de 2007, por la que se establecen disposiciones de aplicación de determinadas prescripciones de la Directiva 2004/109/CE sobre la armonización de los requisitos de transparencia relativos a la información sobre los emisores cuyos valores se admiten a negociación en un mercado regulado (DOUE L 69, de 9 de marzo de 2007, p. 27); b) en relación con los acreedores, estarían los posibles cambios en la legislación concursal, en la legislación procesal, o en el derecho contractual, así como en determinadas normas de protección de los acreedores (p. ej. aquellas relativas a los requisitos de capital o a las operaciones vinculadas), y c) en relación con los trabajadores, tendríamos la modificación de la estructura del Consejo y, por tanto, del sistema de representación de los trabajadores, como resultado de posibles cambios en el derecho societario aplicable a la sociedad (sobre esta cuestión, véase CATHIARD, op. cit., nota 45, pp. 73 y 75). A este respecto, un completo análisis de las consecuencias para los socios, acreedores y trabajadores de la sociedad que lleva a cabo un traslado transfronterizo del domicilio social con mantenimiento de la personalidad jurídica y cambio de la lex societatis puede encontrarse GARCIMARTÍN ALFÉREZ, op. cit., nota 5, pp. 115-123.

${ }^{121}$ A este respecto, y en relación con la aprobación de la operación por parte de la junta de accionistas, el Parlamento Europeo opta en sus Recomendaciones por exigir «la mayoría necesaria para modificar los estatutos sociales con arreglo a la legislación 
legalidad del procedimiento de traslado por parte de las autoridades competentes de los Estados miembros de origen y de destino; g) el deber de inscripción registral de la sociedad en el Estado miembro de destino y su baja en el Registro del Estado miembro de origen, o h) la imposibilidad de que las sociedades inmersas en procedimientos de disolución, liquidación, insolvencia, suspensión de pagos o similares puedan llevar a cabo el traslado transfronterizo de su sede social ${ }^{122}$.

Ciertamente, la regulación de estas cuestiones no debería resultar excesivamente compleja en la medida en que el legislador europeo podría tomar como referencia las normas contempladas en la Directiva 2005/56/CE sobre fusiones transfronterizas (preferentemente) o incluso las previstas en el Reglamento (CE) 2157/2001 sobre la sociedad europea, lo que, a su vez, contribuiría a garantizar un cierto nivel de coherencia interna en el sistema de

aplicable a la sociedad en el Estado miembro de origen», lo que supone un cambio de enfoque frente a la Propuesta de Directiva de 1997 que establecía, como norma general, una mayoría de dos tercios de los votos emitidos, salvo que la ley del Estado miembro en cuestión estableciese un porcentaje superior (art. 4.2), flexibilizando este requisito cuando estaba representado por lo menos la mitad del capital social, caso en el que tan solo resultaba exigible una mayoría simple (art. 6.3).

122 A este respecto, y en relación con los derechos de los acreedores en el marco de estas operaciones, se ha apuntado la conveniencia de incorporar al contenido de la directiva una serie de medidas orientadas a la protección de los derechos de los acreedores y, en particular: a) a prevenir el fórum shopping en materia concursal (impidiendo que sociedades inmersas en procedimientos disolución, liquidación, insolvencia, suspensión de pagos u otros procedimientos análogos puedan llevar a cabo estas operaciones, o estableciendo que, a los efectos de los procedimientos judiciales o administrativos iniciados antes de la operación, se considerará que la sociedad en cuestión tiene su sede social en el Estado miembro de origen); b) a garantizar los derechos de información de los acreedores, lo cual mitigaría los efectos negativos derivados de la información asimétrica que existe entre administradores y acreedores por lo que respecta a las intenciones de la sociedad de llevar a cabo una operación de traslado de domicilio social, o c) a garantizar las deudas de los acreedores (ya fuese de forma automática o sujeta a determinados requisitos), si bien, a los efectos de limitar los costes que esta medida podría suponer para las cuentas de la sociedad que pretende trasladar su domicilio social, podría eximirse la constitución de garantía en determinados supuestos (p. ej. si la sociedad en cuestión conserva un establecimiento permanente en el Estado miembro de origen con bienes suficientes para responder frente a posibles reclamaciones por deudas que puedan surgir con posterioridad al traslado). Sobre esta cuestión, véase MULLER et al., op. cit., nota 78, pp. 45-50. De hecho, el art. 8 de la Propuesta de Directiva de 1997 ya hacía referencia a la obligación de garantizar las deudas surgidas con anterioridad a la publicación del proyecto de traslado. 
derecho societario europeo en materia de operaciones de reorganización empresarial ${ }^{123}$. Ahora bien, dicho lo cual, creemos que, en términos globales y de cara a futuro, tanto la décima directiva como la decimocuarta directiva, deberían profundizar en la armonización de algunos aspectos comunes, tales como la protección de los derechos de los socios minoritarios o de los acreedores ${ }^{124}$.

${ }^{123}$ A título de ejemplo, se ha apuntado la conveniencia de que la decimocuarta directiva contemple una norma de protección de los derechos de participación de los trabajadores similar a la prevista en el art. 16 de la Directiva 2005/56/CE, al objeto de evitar que este elemento se convierta en un factor determinante para la elección de una u otra vía para articular un traslado transfronterizo del domicilio social y/o que los trabajadores pudiesen salir perjudicados en función del mecanismo empleado para realizar la operación (véase MULLER et al., op. cit., nota 78, p. 48).

124 Por otra parte, y en relación con la protección de los derechos de los accionistas minoritarios que se oponen a la operación, las Recomendaciones del Parlamento Europeo, siguiendo lo previsto en el art. 7 de la Propuesta de Directiva de 1997, dejan esta cuestión en manos de los Estados miembros haciendo referencia, a título de ejemplo, a la posibilidad de reconocer un derecho de separación en favor de este colectivo (tal y como, en la actualidad, se contempla en el art. 99 de la LME o en los arts. 2437 y 2473 del Codice Civile italiano). A nuestro juicio, y teniendo en cuenta el impacto negativo que el reconocimiento de este derecho tiene sobre la operación (p. ej. incertidumbre en relación con el número de socios que finalmente ejercitarán este derecho, importe que tendrá que pagar la sociedad por su ejercicio, etc.) y, por ende, sobre la movilidad transfronteriza de las empresas europeas, cabría plantearse la posibilidad de que, aun dejando en manos de los Estados miembros la adopción de medidas tendentes a garantizar los derechos de los socios minoritarios (aspecto que en sí mismo también resulta discutible habida cuenta de los problemas derivados de la divergencia entre los sistemas legislativos de los diferentes Estados miembros), la decimocuarta directiva limitase o directamente excluyese la posibilidad de que dichos Estados miembros pudieran reconocer en sus legislaciones domésticas un derecho de separación en favor de este colectivo. A este respecto, no puede perderse de vista que el importante grado de armonización existente entre las legislaciones de los Estados miembros en materia societaria contribuye a mitigar en gran medida los efectos negativos que un cambio de la lex societatis podría desplegar para este colectivo. No obstante, a nivel interno, y en favor del reconocimiento de un derecho de separación a los socios que hubieran votado en contra del acuerdo de traslado ya se mostraron en su momento BLANCO-MORALES LIMONES, op. cit., nota 6, p. 137, o GARCIMARTÍN ALFÉREZ, op. cit., nota 5, pp. 118-119, que entendía que el derecho de separación suponía un adecuado término medio entre el reconocimiento de un posible derecho de veto (que incrementaría los denominados «riesgos de extorsión» de los socios minoritarios frente a la mayoría) y la no concesión de ningún derecho a este colectivo (que incrementaría los «riesgos de expropiación» por parte de los socios mayoritarios frente a los socios minoritarios). 
En quinto y último lugar, estaría la necesidad de que las operaciones de traslado transfronterizo del domicilio social resultasen fiscalmente neutras. A este respecto, no conviene perder de vista cómo los potenciales beneficios derivados de la aprobación de una norma europea destinada a aportar un marco jurídico adecuado para la realización de estas operaciones podrían quedar enormemente diluidos si no se garantiza la neutralidad fiscal de las mismas, especialmente en el ámbito de la imposición sobre la renta societaria, pero también en relación con otros tributos (p.ej. tasas de registro - registration duties - establecidas por el Estado miembro de destino; impuestos sobre las transmisiones patrimoniales - transfer taxes-). Ciertamente, en la medida en que el traslado del domicilio social determine el cese de la residencia fiscal de la sociedad en su Estado miembro de origen de acuerdo con los criterios de conexión establecidos por su normativa tributaria, dicho Estado podría proceder al gravamen de las plusvalías latentes a través de los denominados «impuestos de salida», aun cuando la realización de estas operaciones con mantenimiento de la personalidad jurídica no suponga stricto sensu una transmisión de elementos patrimoniales.

A este respecto, no puede negarse que la evolución de la jurisprudencia del TJUE sobre la base de la libertad de establecimiento ha permitido a las formas societarias nacionales, en el marco de operaciones de traslado transfronterizo de su sede con cambio de residencia fiscal, beneficiarse de normas de diferimiento impositivo incluso más ventajosas que las contempladas en la directiva fiscal de fusiones (p.ej. con respecto a la exigencia de vinculación de los activos y pasivos de la sociedad a un establecimiento permanente situado en el Estado miembro de origen) ${ }^{125}$, estableciendo una serie de límites a las facultades de los Estados miembros en materia de impuestos de salida entre los que cabría destacar la imposibilidad de que el pago de dichos impuestos pueda exigirse de forma inmediata, debiendo los Estados miembros ofrecer al contribuyente la posibilidad de aplazar su pago hasta el momento de realización efectiva de la plusvalía (caso en el que podrán exigir los correspondientes intereses de acuerdo con la normativa nacional aplicable), o la necesidad de que, en los supuestos en los que el contribuyente opte por el aplazamiento del pago, la constitución de garantía bancaria se imponga en función del riesgo real de que finalmente no se recaude el impuesto ${ }^{126}$.

125 Así lo entienden, Ben TERRA y Peter WATTEL, European Tax Law, Kluwer, Deventer, 2012, p. 670.

126 Véase Sentencias del TJUE de 29 de noviembre de 2011, National Grid Indus BV, C371/10, EU:C:2011:785, apartado 86; y de 23 de enero de 2014, DMC, C164/12, 
De hecho, las legislaciones fiscales de algunos Estados miembros como España ya establecen que, aun cuando la regla general en supuestos de traslado transfronterizo de la sede social o real por parte de sociedades residentes a efectos fiscales en territorio español que determinan un cambio en la residencia fiscal de dichas sociedades consiste en la integración en su base imponible de la diferencia entre el valor de mercado y el valor fiscal de los elementos patrimoniales que figuren bajo su titularidad (a excepción de aquéllos que queden afectados a un establecimiento permanente localizado en España, en relación con los cuales se concede un diferimiento del gravamen de las plusvalías), el pago de la deuda tributaria deberá ser aplazado, a solicitud del contribuyente, hasta la fecha de transmisión a un tercero de dichos elementos patrimoniales, siempre que el Estado miembro de destino sea un Estado miembro de la UE o del EEE con el que exista un efectivo intercambio de información tributaria en los términos previstos en el apartado 4 de la disposición adicional primera de la Ley 36/2006, de 29 de noviembre, de Medidas para la Prevención del Fraude Fiscal ${ }^{127}$, resultando de aplicación lo dispuesto en la Ley 58/2003, de 17 de diciembre, General Tributaria ${ }^{128}$, y su normativa de desarrollo, en cuanto al devengo de intereses de demora y a la constitución de garantías para dicho aplazamiento ${ }^{129}$.

No obstante, debemos tener presente que las medidas implementadas por los Estados miembros con el fin de diferir el pago de los denominados «impuestos de salida» en este tipo de supuestos distan mucho de ser homogéneas ${ }^{130}$. A este respecto, y a la espera de observar la evolución del proyecto de

EU:C:2014:20, apartado 69. Sobre esta cuestión, véase José Manuel CALDERÓN CARRERO, «Las discriminaciones fiscales generadas por el Estado de residencia del contribuyente y el Derecho de la UE: el problema de la importación de pérdidas extranjeras y de los impuestos de salida», en Adolfo MARTÍN JIMÉNEZ y Francisco CARRASCO GONZÁLEZ (dirs.), Impuestos directos y libertades fundamentales del tratado de funcionamiento de la Unión Europea. Cuestiones fundamentales en la jurisprudencia del Tribunal de Justicia de la Unión Europea, Aranzadi, Cizur Menor, 2016, pp. 149-154.

127 BOE núm. 286, de 30 de noviembre de 2006.

128 BOE núm. 302, 18 de diciembre de 2003.

129 Véase art. 19.1 de la Ley 27/2014, de 27 de noviembre, del Impuesto sobre Sociedades.

${ }^{130}$ Por ejemplo, en Francia, el traslado transfronterizo de la sede (social o real) de una sociedad residente a efectos fiscales en territorio francés a un Estado miembro de la UE o bien a un Estado miembro del EEE (que hubiese suscrito con Francia un Convenio de asistencia administrativa para luchar contra el fraude o la evasión fiscal así como un Convenio de asistencia mutua en materia de recaudación cuyo conteni- 
base imponible consolidada común del impuesto sobre sociedades (relanzado a finales del año 2016 por parte de las instituciones europeas ${ }^{131}$ ), no puede perderse de vista que la aprobación de la Directiva 2016/1164/UE ${ }^{132}$ ya ha permitido dar una respuesta desde el plano del derecho positivo europeo a este tipo de supuestos, contribuyendo de forma decisiva a superar las limitaciones inherentes al carácter casuístico de la jurisprudencia del TJUE, mitigando en cierta medida los problemas de seguridad jurídica derivados del carácter heterogéneo de las legislaciones domésticas de los Estados miembros en materia de impuestos de salida ${ }^{133}$.

do sea similar al de la Directiva 2010/24/UE del Consejo de 16 de marzo de 2010, sobre la asistencia mutua en materia de cobro de los créditos correspondientes a determinados impuestos, derechos y otras medidas -DOUE L 84, de 31 de marzo de 2010, p. 1-) acompañado de la transmisión de un conjunto de activos que no quedasen vinculados a un EP situado en Francia con posterioridad a la operación, daría lugar al gravamen inmediato de las plusvalías latentes, aplazadas o diferidas vinculadas a dichos activos. Sin embargo, la sociedad en cuestión puede optar entre el pago inmediato de la deuda tributaria o solicitar su fraccionamiento hasta en cinco años. Ahora bien, en el caso de que en dicho periodo de tiempo se produzca la transmisión de los activos a un tercero, el traslado de los mismos a un Estado no miembro, la disolución de la sociedad, o no se realice el pago de una de las anualidades fijadas, el importe de la deuda tributaria resultará inmediatamente exigible (véase art. 221.2 del CGI). Asimismo, y aunque el Code Général des Impôts (CGI) guarda silencio al respecto, las autoridades tributarias han aclarado que, en este tipo de supuestos de traslado transfronterizo de la sede a Estados miembros de la UE o del EEE, la operación resulta fiscalmente neutra por lo que respecta a los socios de la sociedad en cuestión con independencia de que se produzca o no una transmisión de elementos de activo en el marco de la misma (véase BOI-IS-CESS-30 (03.07.2013). El documento resulta accesible a través del enlace http://bofip. impots.gouv.fr/bofip/8653-PGP. html?identifiant=BOI-IS-CESS-30-20130703 (consultado por última vez el 28-3-2017)).

${ }^{131}$ En este sentido, podría traerse a colación la Propuesta de Directiva del Consejo de 25 de octubre de 2016, relativa a una base imponible consolidada común del impuesto sobre sociedades (BICCIS), COM (2016) 683 final, y la Propuesta de Directiva del Consejo de 25 de octubre de 2016, relativa a una base imponible común del impuesto sobre sociedades, Estrasburgo, COM (2016) 685 final.

132 Directiva 2016/1164/UE del Consejo de 12 de julio de 2016 por la que se establecen normas contra las prácticas de elusión fiscal que inciden directamente en el funcionamiento del mercado interior (DOUE núm. 193, de 19 de julio de 2016, p. 1).

${ }^{133}$ Un buen análisis sobre su contenido puede encontrarse en José Manuel CALDERÓN CARRERO y Adolfo MARTÍN JIMÉNEZ, «La Directiva UE 2016/1164 contra las prácticas de elusión fiscal que inciden en el mercado interior: ¿El principio del final de 
De este modo, y de acuerdo con lo establecido en el art. 5.2 de la Directiva 2016/1164/UE, en aquellos supuestos de traslado transfronterizo de la sede social o real de una sociedad establecida y residente a efectos fiscales en un Estado miembro hacia otro Estado miembro de la UE o del EEE que de como resultado un cambio de su residencia fiscal, deberá otorgarse a la sociedad en cuestión el derecho a aplazar el pago del impuesto de salida derivado del gravamen de las plusvalías latentes de los elementos patrimoniales de su titularidad que no permanezcan vinculados de manera efectiva a un establecimiento permanente localizado en el Estado miembro de origen, fraccionándolo a lo largo de cinco años ${ }^{134}$. En caso de que la sociedad se inclinase por esta opción, cabría señalar cómo el Estado miembro de origen en el que estaba situada su residencia a efectos fiscales con anterioridad a la operación podría, por una parte, exigir intereses de acuerdo con lo establecido en su normativa doméstica y, por otra, imponer la constitución de garantía como condición para el aplazamiento del pago en aquellos supuestos en los que exista un riesgo demostrable y real de impago ${ }^{135}$.

Por su parte, y en relación con los activos trasladados sobre los que se proyecta el diferimiento del pago de los impuestos de salida, el Estado miembro de destino donde se situará la nueva residencia fiscal de la sociedad en cuestión, en principio, deberá aceptar el valor determinado por el Estado

un IS nacional o una pieza más de descoordinación en el nuevo orden post-BEPS?», Revista de Contabilidad y Tributación, núm. 407, 2017, pp. 5-56.

${ }^{134}$ A este respecto, nótese que, siendo el Estado de destino miembro del EEE, la aplicación de la regla de aplazamiento del pago del impuesto de salida prevista por la Directiva requiere la existencia de un acuerdo con el Estado miembro de origen en el que residía la sociedad a efectos fiscales o con la UE sobre asistencia mutua en materia de cobro de créditos tributarios que sea equivalente a la asistencia mutua prevista en la Directiva 2010/24/UE. No obstante, la Directiva establece una serie de supuestos que determinarán la interrupción del aplazamiento del pago y la exigencia inmediata de la deuda tributaria, a saber: a) los activos trasladados fuera del Estado miembro de origen son vendidos o enajenados de algún otro modo; b) dichos activos son posteriormente trasladados a un Estado no miembro de la UE o del EEE; c) la sociedad traslada nuevamente su residencia fiscal a un Estado no miembro de la UE o del EEE; d) la sociedad se encuentra en situación de quiebra o liquidación, y e) la sociedad incumple sus obligaciones en relación con los pagos fraccionados y no procede a corregir su situación a lo largo de un período razonable, que no excederá de doce meses (véase art. 5.4 de la Directiva 2016/1164/UE).

135 Véase art. 5.3 de la Directiva 2016/1164/UE. 
miembro de origen como valor de base de dichos activos a efectos fiscales, a menos que no refleje el valor de mercado ${ }^{136}$.

Por último, cabría señalar que, aun cuando el art. 5.1, apartado c) de la Directiva 2016/1164/UE ya hace referencia a que el traslado transfronterizo de la sede social o real de una sociedad establecida y residente a efectos fiscales en un Estado miembro que determine un cambio de su residencia fiscal no dará lugar a la exigencia de impuestos de salida en relación con aquellos activos que sigan estando vinculados de manera efectiva a un establecimiento permanente de la sociedad en cuestión en su Estado miembro de origen, no estaría de más plantearse la conveniencia de extender el ámbito de aplicación objetivo de la Directiva 2009/133/CE para dar cobertura a la realización de estas operaciones por parte de formas societarias nacionales con independencia de que se produzca o no un cambio en su residencia fiscal, tal y como sucede con la SE y la SCE ${ }^{137}$. Ciertamente, esto permitiría eliminar posibles diferencias de trato con respecto a la SE y a la SCE en relación con el tratamiento fiscal de las provisiones o reservas constituidas con exención total o parcial del impuesto, así como de las pérdidas no compensadas a efectos fiscales, aportaría un mayor nivel de seguridad jurídica al reducir el impacto negativo derivado de las divergencias entre las legislaciones fiscales de los Estados miembros, garantizaría la neutralidad fiscal de estas operaciones en sede de los socios de la sociedad en cuestión, y contribuiría, junto con la Directiva 2016/1164/UE ${ }^{138}$, a reforzar la vigencia efectiva de una hipotética decimocuarta directiva en materia de derecho societario europeo.

136 Véase art. 5.5 de la Directiva 2016/1164/UE. En este sentido, el art. 5.6 de la citada directiva define el concepto de «valor de mercado» como «el importe por el que puede intercambiarse un activo o por el que pueden liquidarse las obligaciones recíprocas entre compradores y vendedores interesados independientes en una transacción directa».

137 Véase arts. 12 a 14 de la Directiva 2009/133/CE. Ahora bien, en la medida en que el traslado transfronterizo del domicilio social se articule a través de una operación de transformación transfronteriza con mantenimiento de la personalidad jurídica y cambio del derecho nacional aplicable a la sociedad, deberá verificarse en todo caso que ambas formas societarias (la adoptada originariamente en el Estado miembro de origen y la adoptada como resultado de la operación en el Estado miembro de destino) cumplen los requisitos establecidos en el art. 3 de la Directiva 2009/133/CE.

138 A este respecto, no puede dejar de mencionarse, sin embargo, que la Directiva 2016/1164/UE y la Directiva 2009/133/CE poseen finalidades muy distintas y, en tal sentido, difícilmente puedan calificarse como medidas de armonización complementarias. 


\section{LA INTENSIFICACIÓN DE LA COMPETENCIA NORMATIVA ENTRE ESTADOS MIEMBROS EN EL PLANO DEL DERECHO SOCIETARIO: UN «EFECTO SECUNDARIO» DE LA JURISPRUDENCIA DEL TJUE EN MATERIA DE LIBERTAD DE ESTABLECIMIENTO Y DE LA POSIBLE ADOPCIÓN DE LA DECIMOCUARTA DIRECTIVA}

A la vista de la evolución de la jurisprudencia del TJUE en el ámbito del traslado transfronterizo de la sede social o real de las sociedades nacionales de los diferentes Estados miembros, bien podría afirmarse que la «interpretación extensiva» de la libertad de establecimiento realizada por el TJUE ha contribuido de forma decisiva, por una parte, a consagrar la autonomía de la voluntad de los socios fundadores por lo que respecta a la elección del derecho societario aplicable a las sociedades cubiertas por el ámbito de aplicación del art. 54 del TFUE, con independencia de dónde se localice su sede real o dónde desarrollen sus actividades económicas (sentencias Centros, Überseering e Inspire Art) y, por otra parte, a potenciar dicha autonomía en relación con el cambio del derecho nacional aplicable a las mismas con posterioridad a su constitución (sentencias SEVIC, Cartesio, y VALE Epitési). Sin embargo, no han faltado voces que han puesto de manifiesto cómo este posicionamiento del TJUE tolerante con el fenómeno del forum shopping ha desplegado un efecto dual, abriendo la puerta a la competencia normativa horizontal entre los Estados miembros en el plano del derecho societario (también denominada «efecto Delaware» ${ }^{139}$ ), pero al mismo tiempo, creando una suerte de competencia vertical entre las sociedades de derecho nacional y las formas societarias de naturaleza europea (p.ej. la Sociedad Europea o la Sociedad Cooperativa Europea) ${ }^{140}$.

Si nos centramos en la competencia normativa entre Estados miembros (regulatory competition $)^{141}$, cabría apuntar cómo, desde un punto de vista teórico, la existencia de este fenómeno en el ámbito societario parece quedar su-

139 Sobre los orígenes de este fenómeno véase BLANCO-MORALES LIMONES, $o p$. cit., nota 6, pp. 53-54.

${ }^{140}$ En este sentido, véase Patrick RYAN, «Will There Ever Be a Delaware of Europe?», Columbia Journal of European Law, vol. 11, núm. 1, 2004, pp. 199-200, y Giuseppe PORTALE, «La riforma delle società di capitali tra diritto comunitario e diritto internazionale privato", Europa e diritto privato, núm.1, 2005, pp. 128-129.

141 Una definición de este concepto puede encontrarse en Simon DEAKIN, «Legal diversity and regulatory competition: which model for Europe?», European Law Journal, vol.12, núm. 4, 2006, p. 441, donde se afirma que «la competencia normativa puede ser definida como un proceso mediante el cual las normas jurídicas son elegidas o no elegidas a través de la competencia entre entidades descentralizadas con capacidad 
peditada a la concurrencia de dos requisitos: desde el lado de la oferta, deben existir incentivos para que los legisladores nacionales lleven a cabo reformas normativas que se adapten a las necesidades de las sociedades que pretenden atraer; y, desde el lado de la demanda, debe existir una posibilidad real de elegir el Derecho nacional aplicable a la sociedad, no solo en el momento de su incorporación, sino también con posterioridad a la misma, lo que, en última instancia, dependerá de un análisis de los costes del traslado transfronterizo del domicilio social en relación con sus potenciales beneficios ${ }^{142}$.

A este respecto, no resulta difícil intuir cómo, antes de que vieran la luz las sentencias del TJUE a las que acabamos de hacer referencia, el control de la competencia normativa entre Estados miembros se producía esencialmente desde el lado de la demanda ya que desde la óptica de la oferta lo cierto es que, a pesar de los avances del proceso armonizador (elemento corrector de la competencia normativa por el lado de la oferta), los Estados miembros siempre disponen de importantes incentivos para atraer sociedades a su territorio, especialmente en términos de recaudación y empleo ${ }^{143}$. No obstante, la evolución de la jurisprudencia del TJUE en materia de libertad de establecimiento ha supuesto un factor decisivo de potenciación de la demanda al posibilitar o facilitar, según el caso, el traslado de la sede social (o real) de las sociedades entre Estados miembros con mantenimiento de la personalidad jurídica. Ahora bien, también pueden encontrarse algunas voces más escépticas con el fenómeno de la competencia normativa entre Estados miembros y que se muestran reacias a aceptar que un determinado Estado miembro pueda ejercer una posición dominante sobre el resto por lo que respecta a la atracción de sociedades, habida cuenta de que la decisión acerca del derecho nacional al

reguladora [rulemaking entities], que pueden ser Estados nacionales u otras unidades políticas como regiones o localidades».

142 En este sentido, véase Eva-Maria KIENINGER, «The Legal Framework of Regulatory Competition Based on Company Mobility: EU and US Compared», German Law Journal, vol. 6, núm. 4, 2004, p. 741.

143 A este respecto, tal y como apunta Gustavo VIEIRA DA COSTA CERQUEIRA, «Libre circulation des sociétés en Europe: concurrence ou convergence des modèles juridiques ?», Revue trimestrielle de droit européen, núm. 1, 2014, p. 17, el derecho societario y el derecho tributario juegan un papel fundamental como mecanismos tradicionales de atracción de sociedades hacia el territorio de un determinado Estado. En particular, y por lo que respeta al ámbito del derecho societario, algunas de las principales materias sobre las que actúan los legisladores nacionales serían los requisitos de capital social, las condiciones de registro y constitución, el contenido de los estatutos sociales, las estructuras de gobierno de las sociedades, o las normas específicas aplicables a grupos de sociedades. 
que sujetar la sociedad no solo depende de la legislación societaria del Estado miembro en cuestión, sino de otros factores como la calidad y efectividad de la Administración o del sistema judicial ${ }^{144}$.

En cualquier caso, lo cierto es que podrían traerse a colación varias reformas normativas que muestran una clara tendencia hacia la flexibilización y simplificación del derecho societario en el ámbito de los Estados miembros, a saber: en Francia, la Ley 2003/721, de 1 de agosto de 2003, para la Iniciativa Económica (JORF núm. 179, de 5 de agosto de 2003) introdujo a través de su art. 1 una modificación del art. 223.2 del Código de Comercio francés (Code de Commerce) en virtud de la cual se eliminaba la exigencia de un capital mínimo de 7500 euros para las sociedades de responsabilidad limitada de forma tal que, a partir de ese momento, este quedaría fijado libremente por sus estatutos. En España, la hoy derogada Ley 7/2003, de 1 de abril, de la Sociedad Limitada Nueva Empresa (BOE núm. 79, de 2 de abril de 2003, p. 12679) modificaba la Ley $2 / 1995$, de 23 de marzo, de Sociedades de Responsabilidad Limitada (BOE núm. 71, de 24 de marzo de 1995, p. 9181), al objeto de introducir la "sociedad nueva empresa», configurada como un subtipo más «flexible» de sociedad de responsabilidad limitada en relación con los requisitos y condiciones exigidos para su constitución y funcionamiento. En Alemania, la Ley de modernización del derecho de la $\mathrm{GmbH}$ y sobre la lucha contra el abuso, de 23 de octubre de 2008 (BGBI I 2008, 2026), introdujo una nueva modalidad simplificada de sociedad de responsabilidad limitada $(\mathrm{GmbH})$ bajo la denominación Unternehmergesellschaft, siendo una de sus características esenciales la no exigencia de capital mínimo ${ }^{145}$.

Asimismo, también puede observarse un movimiento progresivo de los Estados miembros que tradicionalmente apostaban por la teoría de la sede real hacia modelos mixtos más o menos próximos, según el caso, a la teoría de la sede social. De este modo, y a título de ejemplo, podría señalarse cómo en Alemania, a través de una reforma normativa operada en el año 2008, se abrió la puerta a la separación de la sede social y la sede real de las sociedades anónimas (Aktiengesellschaft) y de las sociedades de responsabilidad limitada

${ }^{144}$ En este sentido, véase Tobias TRÖGER, «Choice of Jurisdiction in European Corporate Law. Perspectives of European Corporate Governance», European Business Organization Law Review, vol. 6, núm. 1, 2005, pp. 63-64.

145 Un buen análisis de las adaptaciones normativas llevadas a cabo por Alemania y Países Bajos para reforzar el atractivo de su derecho societario y dar respuesta a los retos que planteaba el incremento del nivel de movilidad transfronteriza de las sociedades puede encontrarse en William BRATTON, Joseph McCAHERY y Erik VERMEULEN, "How Does Corporate Mobility Affect Lawmaking? A Comparative Analysis», American Journal of Comparative Law, vol. 57, núm. 2, 2009, pp. 380-384. 
$(G m b H)$ sin que esto supusiese la pérdida de su personalidad jurídica. En una línea similar, otros Estados miembros como Eslovaquia (2004) o Hungría (2007) también han llevado a cabo reformas en sus sistemas legislativos que apuestan de forma decisiva por el modelo de la sede social ${ }^{146}$.

Ciertamente, estas reformas normativas deben enmarcarse en un contexto de competencia normativa «a la baja» (race to the bottom) entre Estados miembros ${ }^{147}$ orientado a la atracción de sociedades y actividad económica a sus respectivos territorios y en el que, si se nos permite la expresión, el enemigo que batir era el Reino Unido ${ }^{148}$. Asimismo, no conviene perder de vista cómo la posible adopción de una norma europea que posibilite de forma definitiva el traslado transfronterizo del domicilio social, siguiendo el camino iniciado por las sentencias SEVIC, Cartesio, y VALE Épitési, por una parte garantizaría a todas las sociedades cubiertas por el ámbito de aplicación del art. 54 del TFUE, con independencia de su origen, el acceso a legislaciones societarias más ventajosas situándolas en un cierto plano de igualdad con aquellas sociedades originariamente constituidas en Estados miembros con ordenamientos más flexibles en esta materia, pero, por otro lado, constituiría un factor que contribuiría a intensificar la competencia normativa entre Estados miembros, especialmente si la decimocuarta directiva (a la que nos referiremos en el siguiente epígrafe) finalmente opta por no exigir que el traslado transfronterizo

146 Sobre esta cuestión, véase VIEIRA DA COSTA CERQUEIRA, op. cit., nota 143, pp. 20-24.

147 En este sentido, véase Horatia MUIR WATT, «Note sur l'arrêt de la Cour de justice des Communautés européennes du 30 septembre 2003, Revue critique de droit international privé, vol. 93, núm. 1, 2004, p. 177.

148 En este sentido, cabría señalar que, como resultado de las sentencias Centros, Überseering e Inspire Art, se observó un incremento notable de las sociedades registradas en Reino Unido que mantenían su sede real o llevaban a cabo la mayor parte de su actividad en otros Estados miembros. Así, a título de ejemplo, cabría observar cómo, en el año 2005, había 12019 sociedades registradas en Reino Unido que operaban en Alemania, frente a las 516 que se contabilizaban en el año 2001, y 2127 sociedades registradas en Reino Unido que desarrollaban sus actividades en Países Bajos, frente a las 91 que se contabilizaban en el año 2001 (véase Philippe PELLÉ, «Companies crossing borders within Europe», Utrech Law Review, vol. 4, núm. 1, 2008, p. 10). Un estudio empírico en profundidad que demuestra este fenómeno y el papel del Reino Unido como Estado miembro «receptor» de sociedades que no llevan a cabo actividades dentro de su territorio puede encontrarse en Marco BECHT, Colin MAYER, y Hannes WAGNER, "Where do firms incorporate? Deregulation and the cost of entry», Journal of Corporate Finance, vol. 14, núm. 3, 2008, pp. 241-256. 
del domicilio social venga acompañado necesariamente del traslado simultáneo de la sede real al mismo Estado miembro ${ }^{149}$.

Sin embargo, es importante tener presente que un escenario en el que las sociedades puedan optar por el régimen jurídico que les resulte más ventajoso, ya de sea de forma originaria o con posterioridad a su constitución, no tiene que resultar necesariamente negativo desde el punto de vista del proceso de integración de la Unión Europea dado que la competencia normativa entre jurisdicciones podría traducirse en un incremento de la competitividad de las empresas europeas, o bien, incentivar a los Estados miembros a profundizar en el proceso de armonización, elevando de forma consensuada los estándares normativos en relación con determinados aspectos de sus respectivos derechos societarios nacionales. Ciertamente, y en la medida en que la elaboración de normas europeas obligaría a los Estados miembros que hubiesen adoptado unos estándares más bajos en materia societaria a elevarlos, reduciendo de este modo el atractivo de su derecho nacional, podría afirmarse que la armonización del derecho societario se configura como una suerte de mecanismo de protección para aquellos Estados miembros interesados en defender sus respectivos sistemas legislativos nacionales frente a otros Estados miembros con regímenes normativos más atractivos ${ }^{150}$. En esta misma línea, algunas voces dentro de la doctrina defienden que, un contexto de competencia normativa, favorece la importación por parte de los Estados miembros de aquellos modelos jurídicos que han sido "validados» por el propio entorno económico lo que, a su vez, contribuye al desarrollo de una suerte de proceso de convergencia espontáneo entre los derechos nacionales de los Estados miembros ${ }^{151}$.

En nuestra opinión, el enfoque «de mínimos» adoptado por algunas de las normas más representativas del proceso de armonización del derecho societario europeo (p.ej. la Directiva 2005/56/CE), con numerosas remisiones a las legislaciones nacionales, refleja la idea de que un cierto nivel de competencia normativa entre Estados miembros no resulta necesariamente negativa para la integración y buen funcionamiento del mercado interior ${ }^{152}$. Por otra parte, también se ha apuntado que la libre elección del derecho aplicable no debería

149 Así lo entiende, FRADA DE SOUSA, op. cit., nota 83, p. 63.

${ }^{150}$ En este sentido, véase WYMEERSCH, op. cit., nota 107, p. 162, y PELLÉ, op. cit., nota 148, p. 7.

151 Sobre esta cuestión, véase VIEIRA DA COSTA CERQUEIRA, op. cit., nota 143, pp. 14-27.

152 De hecho, la propia Comisión Europea ha reconocido que un cierto grado de competencia normativa podría incluso contribuir de forma positiva la eficacia del mercado interior (Véase COMISIÓN EUROPEA, «Comunicación de la Comisión al Consejo y al Parlamento. Modernización del Derecho de sociedades y mejora de la gobernanza 
suponer un problema para los terceros que contratan con la sociedad ya que, en la medida en que estos estén informados acerca de la legislación por la que se rige la sociedad con la que se relacionan, siempre disponen de la opción de trasladar al precio el riesgo que asumen al contratar con sociedades sujetas a ordenamientos domésticos poco garantistas con sus intereses ${ }^{153}$.

Ahora bien, lo que no puede negarse es que las mejoras en el nivel de movilidad transfronteriza de las sociedades nacionales de los diferentes Estados miembros derivadas de la jurisprudencia del TJUE han supuesto un duro revés para las formas societarias de naturaleza europea que, encorsetadas en un estricto y poco flexible régimen jurídico, han visto disminuir en gran medida el atractivo que presentaban en el momento de su aparición. En esta misma línea, la adopción de una norma de derecho societario europeo que establezca un marco jurídico-procedimental para las operaciones de traslado transfronterizo del domicilio social de las sociedades de los diferentes Estados miembros y posibilite su realización con los adecuados niveles de seguridad jurídica no vendría sino a intensificar la competencia vertical entre las sociedades de derecho nacional y las formas societarias de naturaleza europea.

\section{CONCLUSIONES}

A lo largo de este trabajo hemos tenido ocasión de comprobar cómo, si bien antes de la entrada en el nuevo milenio las legislaciones societarias de algunos Estados miembros (p.ej. España, Francia o Italia) ya contenían disposiciones orientadas a posibilitar el traslado transfronterizo de la sede social desde y hacia su territorio sin que esto supusiera la disolución y liquidación de la sociedad en su Estado miembro de origen, su vigencia efectiva resultaba, en ocasiones, más teórica que práctica. Por ello, podría afirmarse que la jurisprudencia del TJUE en el ámbito de la libertad de establecimiento ha contribuido de forma decisiva a posibilitar o facilitar, según el caso, el traslado transfronterizo de la sede social entre Estados miembros con mantenimiento de la personalidad jurídica, fundamentalmente a través de operaciones de transformación transfronteriza con cambio del derecho nacional aplicable.

empresarial en la Unión Europea: Un plan para avanzar», COM (2003) 284 final, 21.5.2003, p. 10).

153 En este sentido, véase Alfonso Luis CALVO CARAVACA y Javier CARRASCOSA GONZÁLEZ, «Sociedades mercantiles: libertad de establecimiento y conflicto de leyes en la Unión Europea», Estudios de Deusto, Universidad de Deusto, vol. 55, núm. 1, 2007, p. 70 . 
Sin embargo, lo cierto es que todavía existen obstáculos de naturaleza jurídica que dificultan las operaciones de traslado, afectando negativamente a la movilidad transfronteriza de las empresas europeas y, por ende, a su competitividad en el plano internacional. Ciertamente, la delimitación por parte del Tribunal de las facultades de los Estados miembros a la hora de imponer requisitos y condiciones a la realización de estas operaciones sobre la base de la interpretación de los arts. 49 y 54 del TFUE no impide que, a falta de una norma europea de referencia en la materia, el carácter heterogéneo de las legislaciones societarias nacionales siga constituyendo un importante hándicap para llevar a cabo el traslado transfronterizo del domicilio social, especialmente desde la óptica de la seguridad jurídica, por no hablar de la existencia de Estados miembros que ni siquiera han adoptado disposiciones normativas internas orientadas a facilitar estas operaciones.

Asimismo, el recurso a las "vías indirectas» que ofrecen el Reglamento (CE) 2157/2001 y la Directiva 2005/56/CE en su redacción actual no constituye una solución óptima a largo plazo pues, aun cuando el uso instrumental de dichas normas permite una mejor protección de los principales colectivos afectados por el traslado transfronterizo del domicilio social y aporta, en muchas ocasiones, mayores niveles de seguridad jurídica en comparación con la realización de dichas operaciones a través de la aplicación «directa» de las legislaciones societarias de los Estados miembros involucrados en la operación, plantean algunos problemas vinculados a la falta de flexibilidad de su régimen jurídico - Reglamento (CE) 2157/2001- o al incremento del coste global de la operación (Directiva 2005/56/CE).

Por ello, y una vez que la experiencia práctica ha permitido constatar que la «no acción» en esta materia no es el camino que debe seguirse y que los objetivos pretendidos no pueden ser alcanzados de manera suficiente a través de la acción de los Estados miembros, el legislador europeo debería abordar de una vez por todas la regulación del traslado transfronterizo del domicilio social a través de normas de derecho positivo, ya sea mediante la elaboración de una directiva en esta materia o bien mediante la incorporación de disposiciones específicas para estas operaciones en el ámbito de la Directiva 2005/56/ $\mathrm{CE}$, con el fin de garantizar efectivamente la libertad de establecimiento de las sociedades constituidas de acuerdo con la legislación de un Estado miembro y cubiertas por el ámbito de aplicación del art. 54 del TFUE.

Ciertamente, la adopción sobre la base del art. 50.1 del TFUE de una directiva específica en materia de traslado transfronterizo de domicilio social que establezca el régimen jurídico esencial al que deben sujetarse estas operaciones así como el procedimiento para llevarlas a cabo, siguiendo en líneas generales las recomendaciones apuntadas por el Parlamento Europeo, contribuiría en gran medida a: a) fomentar la movilidad transfronteriza de las socie- 
dades de los Estados miembros, permitiéndoles el acceso a regímenes jurídicos y fiscales más laxos que los de su Estado miembro de constitución, lo que se traduciría, entre otras cuestiones, en un ahorro de recursos, en una reducción de los costes de cumplimiento, así como en una mejora de la capacidad de atracción de recursos financieros; b) incrementar el nivel de seguridad jurídica - p.ej. en relación con las obligaciones de los órganos de dirección y administración de la sociedad, los requisitos que deberán cumplirse para poder llevar a cabo la operación, los derechos de los colectivos afectados por la operación, o las facultades de los Estados miembros-; c) simplificar el procedimiento a través del cual vienen desarrollándose estas operaciones; d) reducir los costes asociados al uso de vías o fórmulas indirectas para la realización del traslado transfronterizo del domicilio social, y e) garantizar los derechos de los trabajadores, accionistas minoritarios y acreedores en el marco de estas operaciones, al tiempo que permitiría respetar determinadas especificidades propias de los derechos societarios nacionales lo que aportaría flexibilidad a su aplicación.

En último lugar, y por lo que respecta a las voces críticas que llaman la atención acerca de que el establecimiento de un régimen jurídico-procedimental de naturaleza europea que, siguiendo el camino iniciado por las sentencias SEVIC, Cartesio, y VALE Épitési, facilite el traslado transfronterizo del domicilio social, daría como resultado una intensificación de la competencia normativa «a la baja» entre Estados miembros (race to the bottom) con el objetivo de atraer sociedades a sus respectivos territorios (efecto Delaware), cabría señalar que el hecho de que las sociedades nacionales puedan optar por el régimen jurídico que les resulte más ventajoso, ya de sea de forma originaria o con posterioridad a su constitución, no tiene que resultar necesariamente negativo desde el punto de vista del proceso de integración de la Unión Europea dado que la competencia normativa entre jurisdicciones podría traducirse en un incremento de la productividad y competitividad de las empresas europeas (vía reducción de costes, simplificación de procedimientos o mejora de la capacidad de captar recursos financieros) o bien, incentivar a los Estados miembros a profundizar en el proceso de armonización, elevando de forma consensuada los estándares normativos en relación con determinados aspectos de sus respectivas legislaciones societarias nacionales. En este sentido, no puede perderse de vista que el proceso de armonización del derecho societario europeo puede configurarse como una suerte de mecanismo de protección para aquellos Estados miembros interesados en defender sus respectivos ordenamientos domésticos frente a otros Estados miembros con regímenes normativos más atractivos.

Ahora bien, si nos trasladamos al ámbito de la «competencia vertical» entre las sociedades de derecho nacional y las formas societarias de naturaleza europea, no puede negarse que la adopción de una norma de derecho europeo 
que mejorase significativamente la movilidad transfronteriza de las sociedades de los diferentes Estados miembros supondría un duro revés para las formas societarias de naturaleza europea que, encorsetadas en un estricto y poco flexible régimen jurídico, verían desaparecer uno de los elementos de ventaja comparativa sobre los que se fundamentaba buena parte de su atractivo en el momento de su aparición hace más de una década en el panorama societario europeo y que ya se había visto diluido por la evolución de la jurisprudencia del TJUE. 